See discussions, stats, and author profiles for this publication at: https://www.researchgate.net/publication/223577388

\title{
Methane and sulfide fluxes in permanent anoxia: In situ studies at the Dvurechenskii mud volcano (Sorokin Trough, Black Sea)
}

Article in Geochimica et Cosmochimica Acta - September 2010

DOI: 10.1016/j.gca.2010.05.031

CITATIONS

27

7 authors, including:

\section{Anna Lichtschlag}

National Oceanography Centre, Southampton

73 PUBLICATIONS 1,244 CITATIONS

SEE PROFILE

Frank Wenzhoefer

Alfred Wegener Institute Helmholtz Centre for Polar and Marine Research 189 PUBLICATIONS 4,797 CITATIONS

SEE PROFILE

\section{READS}

28

2 Janine Felden

Universität Bremen

57 PUBLICATIONS 764 CITATIONS

SEE PROFILE

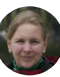

Florence Schubotz

Universität Bremen

98 PUBLICATIONS 1,399 CITATIONS

SEE PROFILE

Some of the authors of this publication are also working on these related projects:

HYPOX WP4:Indicators of past hypoxia dynamics: improving long term records by abiotic and biotic proxies View project

Methanotrophic microbiome View project 


\title{
Methane and sulfide fluxes in permanent anoxia: In situ studies at the Dvurechenskii mud volcano (Sorokin Trough, Black Sea)
}

\author{
Anna Lichtschlag ${ }^{\mathrm{a}, *}$, Janine Felden $^{\mathrm{a}}$, Frank Wenzhöfer ${ }^{\mathrm{a}, \mathrm{b}}$, Florence Schubotz ${ }^{\mathrm{c}}$, \\ Tobias F. Ertefai ${ }^{\mathrm{c}, 1}$, Antje Boetius ${ }^{\mathrm{a}, \mathrm{b}}$, Dirk de Beer ${ }^{\mathrm{a}}$ \\ ${ }^{a}$ Max-Planck-Institute for Marine Microbiology, Celsiusstrasse 1, 28359 Bremen, Germany \\ ${ }^{\mathrm{b}}$ HGF MPG Research Group on Deep Sea Ecology and Technology, Alfred-Wegener-Institute for Polar and Marine Research, \\ Am Handelshafen 12, 27570 Bremerhaven, Germany \\ ${ }^{\mathrm{c}}$ MARUM, Center for Marine Environmental Sciences and Department of Geosciences, University of Bremen, Leobener Strasse, \\ 28359 Bremen, Germany
}

Received 3 August 2009; accepted in revised form 20 May 2010; available online 2 June 2010

\begin{abstract}
The Dvurechenskii mud volcano (DMV) is located in permanently anoxic waters at $2060 \mathrm{~m}$ depth (Sorokin Trough, Black Sea). The DMV was studied during the RV Meteor expedition M72/2 as an example of an active mud volcano system, to investigate the significance of submarine mud volcanism for the methane and sulfide budget of the anoxic Black Sea hydrosphere. Our studies included benthic fluxes of methane and sulfide, as well as the factors controlling transport, consumption and production of both compounds within the sediment. The pie-shaped mud volcano showed temperature anomalies as well as solute and gas fluxes indicating high fluid flow at its summit north of the geographical center. The anaerobic oxidation of methane (AOM) coupled to sulfate reduction (SR) was repressed in this zone due to the upward flow of sulfate-depleted fluids through recently deposited subsurface muds, apparently limiting microbial methanotrophic activity. Consequently, the emission of dissolved methane into the water column was high, with an estimated rate of $0.46 \mathrm{~mol} \mathrm{~m}^{-2} \mathrm{~d}^{-1}$. On the wide plateau and edge of the mud volcano surrounding the summit, fluid flow and total methane flux were lower, allowing higher SR and AOM rates correlated with an increase in sulfate penetration into the sediment. Here, between $50 \%$ and $70 \%$ of the methane flux $(0.07-$ $0.1 \mathrm{~mol} \mathrm{~m}^{-2} \mathrm{~d}^{-1}$ ) was consumed within the upper $10 \mathrm{~cm}$ of the sediment. The overall amount of dissolved methane released from the entire mud volcano structure into the water column was significant with a discharge of $1.3 \times 10^{7} \mathrm{~mol} \mathrm{yr}^{-1}$. The DMV maintains also high areal rates of methane-fueled sulfide production and emission of on average $0.05 \mathrm{~mol} \mathrm{~m}^{-2} \mathrm{~d}^{-1}$. This is a difference to mud volcanoes in oxic waters, which emit similar amounts of methane, but not sulfide. However, based on a comparison of this and other mud volcanoes of the Black Sea, we conclude that sulfide and methane emission into the hydrosphere from deep-water mud volcanoes does not significantly contribute to the sulfide and methane inventory of the Black Sea. (c) 2010 Elsevier Ltd. All rights reserved.
\end{abstract}

\section{INTRODUCTION}

Below the chemocline in the permanently anoxic waters of the Black Sea, oxygen, nitrate and most of the reactive iron- and manganese-oxides are depleted. Thus sulfate is

\footnotetext{
* Corresponding author. Tel.: +49 (0)421 2028843.

E-mail address: alichtsc@mpi-bremen.de (A. Lichtschlag).

${ }^{1}$ Present address: Department of Applied Chemistry, Curtin University of Technology, Kent St, Perth, WA 6845, Australia.
}

the principal electron acceptor in organic matter mineralization in the water column and the upper seabed (Eq. (1)). This leads to an accumulation of sulfide in the anoxic water column to concentrations of up to $370 \mu \mathrm{mol} \mathrm{L}^{-1}$ (Neretin et al., 2001).

$2 \mathrm{CH}_{2} \mathrm{O}+\mathrm{SO}_{4}{ }^{2-} \rightarrow \mathrm{HS}^{-}+2 \mathrm{HCO}_{3}{ }^{-}+\mathrm{H}^{+}$

At the Dvurechenskii mud volcano (Bohrmann et al., 2003) and at other methane seeps on the slope off Crimea (Kruglyakova et al., 2002; Michaelis et al., 2002) the 
anaerobic oxidation of methane (AOM) coupled to sulfate reduction (SR) constitutes another metabolic pathway with significant sulfide production. This process is performed by methane oxidizing archaea and associated sulfate reducing bacteria (Hinrichs et al., 1999; Boetius et al., 2000), which gain energy by the following reaction:

$\mathrm{CH}_{4}+\mathrm{SO}_{4}{ }^{2-} \rightarrow \mathrm{HS}^{-}+\mathrm{HCO}_{3}{ }^{-}+\mathrm{H}_{2} \mathrm{O}$

At many active seeps, methane oxidation is limited by the availability of sulfate and oxygen, which must diffuse into the seafloor against an upward pore-water flow (de Beer et al., 2006; Niemann et al., 2006). Hence, the fluidflow velocities of the pore water control the amount of methane and sulfide that is consumed or released into the water column, and fluxes of methane and sulfide differ locally depending on the geological structure of the cold seep system. Previous investigations from cold seeps have shown that modeling from pore-water gradients of retrieved cores tends to underestimate the fluid-flow rates, as the upward transport is stopped and steep gradients of fluid constituents in the sediment are disturbed by outgassing of methane. As a result the relationship between fluid flow and methane consumption is not linear (de Beer et al., 2006; Niemann et al., 2006).

Methane venting from seep sediments into the permanently anoxic water of the Black Sea might be of greater significance for the methane budget than in oxic environments, as the aerobic oxidation of methane is impeded and a larger amount of the greenhouse gas methane might be released into the atmosphere. The absence of benthic organisms positively stimulating AOM by replenishing sulfate in the seafloor (Cordes et al., 2005; Niemann et al., 2006) may also lower the efficiency of the benthic filter against methane. In addition, most of the sulfide produced by AOM may escape from the seafloor, as electron acceptors such as oxygen and nitrate are missing, and hence free-living and symbiotic sulfide-oxidizing bacteria, which are efficient consumers of sulfide in oxic seep systems (Treude et al., 2003; de Beer et al., 2006).

In this study, we visited the Dvurechenskii mud volcano (DMV) in the Black Sea abyss as a natural laboratory to investigate how anoxia and different fluid-flow velocities may influence fluxes of methane and sulfide from an active mud volcano to the anoxic Black Sea hydrosphere. To circumvent biases introduced from sediment retrieval our approach was based on in situ methods. We used a benthic chamber for assessing total exchange rates across the sediment-water interface and a microprofiler for measuring high-resolution geochemical gradients in the sediment.

\section{MATERIALS AND METHODS}

\subsection{Sampling site}

The Dvurechenskii mud volcano is located in the central part of the Sorokin Trough at a water depth of about $2060 \mathrm{~m}$. It has a wide flat plateau with an elliptic shape of 1200 by $800 \mathrm{~m}$ diameter, limited by a steep edge with an elevation of $80 \mathrm{~m}$ above the surrounding seafloor. Mud rises diapirically from a deep source originating in the Maikopi- an formation (Oligocene-Lower Miocene) (Woodside et al., 1997). Fluids ascend from a depth of at least $3 \mathrm{~km}$ and are formed by thermogenic organic matter and silicate alteration processes, resulting in enrichments of $\mathrm{Ba}^{2+}, \mathrm{I}^{-}, \mathrm{Cl}^{-}$, $\mathrm{Sr}^{2+}, \mathrm{Li}^{+}$, and ammonium compared to the Black Sea bottom water. Additionally, these fluids are depleted in sulfide and sulfate and show a higher salinity than seawater. Particulate organic matter content is $2-6 \mathrm{wt} . \%$ at the sediment surface, but decreases to about $1 \mathrm{wt} . \%$ below $5 \mathrm{~cm}$ sediment depth (Aloisi et al., 2004; Wallmann et al., 2006). Temperature anomalies in the water column and in the sediments of the DMV indicate areas with increased fluid and/or mud upflow (Bohrmann et al., 2003; Feseker et al., 2009). The distribution of pore-water components in retrieved cores could be fitted to a transport model assuming upward flow velocities from 0.08 to $0.25 \mathrm{~m} \mathrm{yr}^{-1}$, with highest upflow in the central part of the mud volcano plateau, decreasing towards the edge (Aloisi et al., 2004; Wallmann et al., 2006). Rates of anaerobic oxidation of methane coupled to sulfate reduction were also highest in the central part, and the model predicted a consumption of up to $80 \%$ of the average methane flux (Wallmann et al., 2006). Gas flares extend up to $1300 \mathrm{~m}$ into the water column above the DMV (Greinert et al., 2006), but their source was not located. Gas from dissociated hydrates is mainly composed of methane $(>99.5 \%)$ with low amounts of ethane and propane $(<0.5 \%)$ (Blinova et al., 2003; Feseker et al., 2009). The period sampled here (February/March 2007) was characterized by locally higher temperature gradients on the plateau compared to earlier observations (summarized in Feseker et al., 2009), the presence of gas hydrates below $1.5 \mathrm{~m}$ sediment depth with in situ concentrations of $1.7 \mathrm{mmol} \mathrm{CH}_{4} \mathrm{~cm}^{-3}$, and the presence of a relatively young, warm mud flow forming a small elevation north of the center of the mud volcano plateau (Feseker et al., 2009).

\subsection{Sampling}

The DMV was visited during the RV Meteor M72/2 cruise in February/March 2007. High quality videographic observation at this site was accomplished using the cameras of the remotely operated vehicle (ROV) Quest 4000 (MARUM, Bremen), and recording of topographic maps was carried out with the multibeam sonar of the research vessel (Fig. 1). In a small area ( $4^{\circ} 17.03^{\prime}$; E $\left.34^{\circ} 58.88^{\prime}\right)$ north of the geographical center of the mud volcano the multibeam maps showed an elevation (further referred to as 'summit') of the seafloor of around 2-3 m above the surrounding area, at $2055 \mathrm{~m}$ below sea level.

The bottom water temperature measured across the DMV with temperature loggers mounted on the ROV frame was on average $9.11^{\circ} \mathrm{C}$. At the summit, an anomaly of $+0.01^{\circ} \mathrm{C}$ was recorded in the bottom water at around $60 \mathrm{~cm}$ above the sediment (Feseker et al., 2009). Elevated water temperature is a reliable indicator for discharge of warm fluids. Thus we sampled along a gradient in fluid flow from the DMV summit to the outer edge of the mud volcano plateau. Our target sites were the summit (St. 1), the plateau between the summit and the edge of the mud volcano (with St. 2: geographical center and St. 4-7: transect 


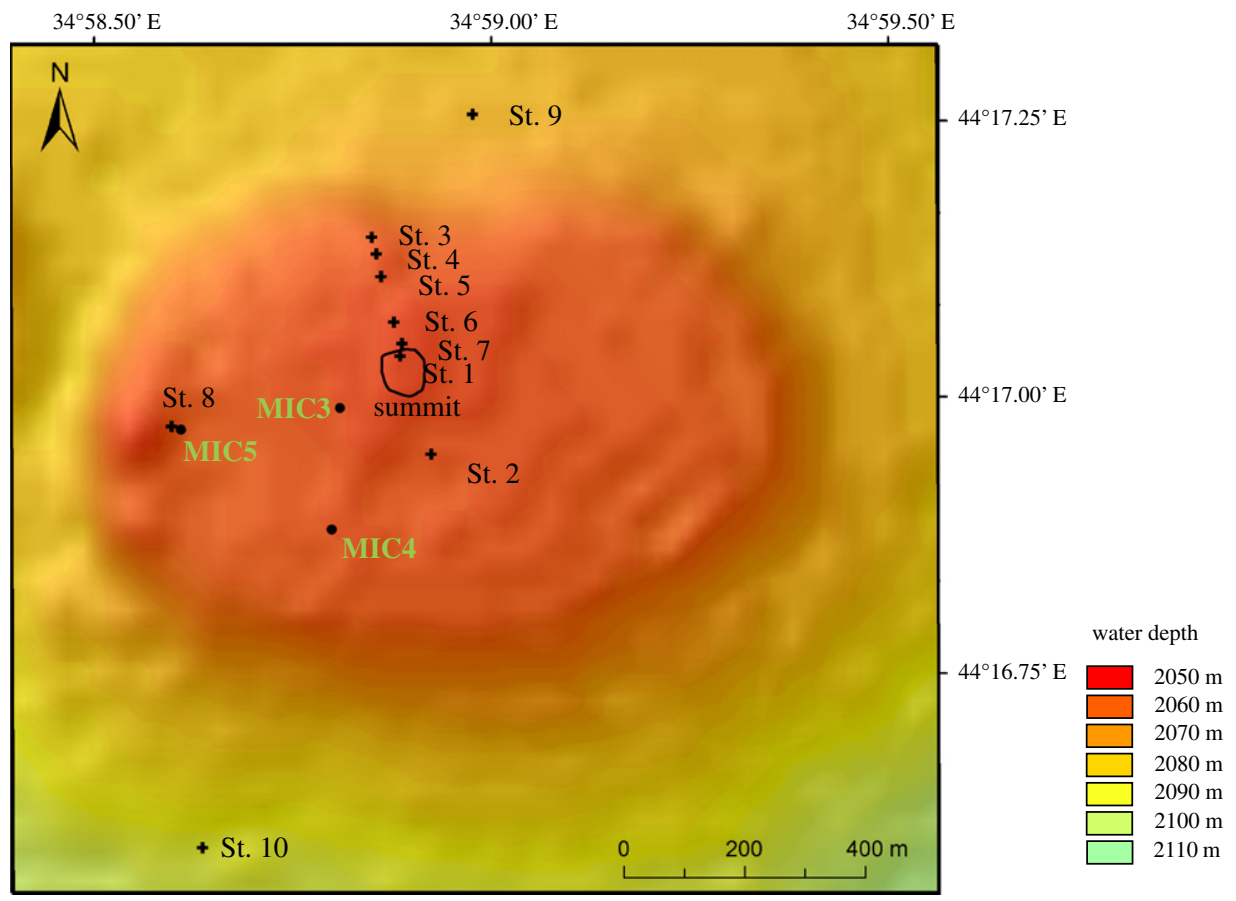

Fig. 1. Bathymetric map of the DMV generated during the M 72/2 cruise with sampling stations (St. 1-10, displayed as +). Additionally, sampling positions MIC 3-5 from Wallmann et al. (2006) and Aloisi et al. (2004) are displayed as

between the summit and the northern edge), the northern and western edge (St. 3, St. 8), and sites north and south of the DMV (St. 9, St. 10). Sediment sampling was done with short sediment cores (push cores: 10-20 cm sediment length) operated by the ROV manipulator, with a TVguided multiple corer (TV-MUC, $20-40 \mathrm{~cm}$ sediment core length) equipped with a POSIDONIA positioning system, and with a gravity corer (up to $4 \mathrm{~m}$ sediment length). Sampling locations are displayed in Fig. 1 and samples were labeled according to the international geoscience database PANGAEA (Table 1).

\subsection{In situ microsensor measurements and flux calculations}

High-resolution geochemical gradients were measured in situ with a deep-sea microprofiler (Fig. 2a), a similar unit as mounted on free-falling lander (Gundersen and Jørgensen, 1990; Wenzhöfer et al., 2000). For measurements the profiler was precisely positioned at the seafloor with the ROV and started with the ROV manipulator. After the profiling was finished, the microprofiler was moved to another station and the measuring routine was re-activated with the ROV arm (Treude et al., 2009). Altogether eight microprofiler deployments were done along a transect from St. 2 as the most southern point towards the northern edge (St. 3) (Fig. 1). Here the profiler was deployed as close as possible $(10 \mathrm{~cm})$ to a crack in the sediment that was filled with white matter (further referred to as 'white patches'). The transect crossed the summit twice (St. 1a, b).

The microprofiler was equipped with three $\mathrm{H}_{2} \mathrm{~S}$ sensors, two $\mathrm{pH}$ sensors, and one $3 \mathrm{~mm}$ thick temperature sensor ( $\mathrm{Pt}$ 100, Umweltsensortechnik GmbH, Germany) (Jeroschewski et al., 1996; de Beer et al., 1997). The sensors were calibrated at in situ temperature as described previously (Wenzhöfer et al., 2000; de Beer et al., 2006). The results from the $\mathrm{H}_{2} \mathrm{~S}$ sensors were converted to total sulfide concentrations with a $\mathrm{pK}_{1}$ for sulfide in seawater after Goldhaber and Kaplan (1975) and will further be referred to as sulfide $\left(=\mathrm{H}_{2} \mathrm{~S}+\mathrm{HS}^{-}+\mathrm{S}^{2-}\right)$.

Diffusive sulfide fluxes across the sediment-water interface were calculated from the gradients in the diffusive boundary layer (DBL) using Ficks first law of diffusion:

$J_{\text {diff }}=D \frac{d c}{d z}$,

where $J_{\text {diff }}=$ diffusive flux $\left[\mathrm{mmol} \mathrm{m}{ }^{-2} \mathrm{~d}^{-1}\right], D=$ diffusion coefficient in water $\left[\mathrm{m}^{2} \mathrm{~d}^{-1}\right]$ corrected for temperature and salinity (Li and Gregory, 1974), and $d c / d z=$ concentration gradient $\left[\mathrm{mmol} \mathrm{m}^{-3} \mathrm{~m}^{-1}\right]$. A diffusion coefficient $D$ for $\mathrm{HS}^{-}$ of $1.05 \times 10^{-4} \mathrm{~m}^{2} \mathrm{~d}^{-1}$ was used. Fluxes in the sediment were calculated from the pore-water gradients:

$J_{\text {diff }}=\phi D_{\text {sed }} \frac{d c}{d z}$,

where $\phi=$ porosity and $D_{\text {sed }}=$ diffusion coefficient in the sediment $\left[\mathrm{m}^{2} \mathrm{~d}^{-1}\right]$. The diffusion coefficient $D_{\text {sed }}$ in the sediment was calculated according to Iversen and Jørgensen (1993):

$D_{\text {sed }}=\frac{D}{1+3(1-\phi)}$

\subsection{Benthic chamber measurements}

A benthic chamber module constructed for the deployment by an ROV as described in Glud et al. (2009) was positioned at St. 1 on the DMV summit (Fig. 2b). Subsam- 
Table 1

Sampling and analysis details from the different areas of the Dvurechenskii mud volcano (DMV). Samples and in situ instruments are labeled as in the PANGAEA database (http://www.pangaea.de) and data is deposited under http://doi.pangaea.de/10.1594/PANGAEA.738356. SR: sulfate reduction, AOM: anaerobic oxidation of methane, AODC: acridine orange direct counts.

\begin{tabular}{|c|c|c|c|}
\hline Station & Mud volcano area & Coordinates & Measurement and PANGAEA event label \\
\hline St. 1a, St. 1b & Summit & $\begin{array}{l}44^{\circ} 17.03^{\prime} \mathrm{N} \\
34^{\circ} 58.88^{\prime} \mathrm{E}\end{array}$ & $\begin{array}{l}\text { Microsensor measurements (M72/2_309_MICP-1, MICP-8), } \\
\text { benthic chamber deployment (M72/2_319_CHAM-1), } \\
\text { SR, AOM (M72/2_309_PUC-68, -36,), } \\
\text { geochemical analyses (M72/2_309_PUC-51, } \\
\text {-21, M72/2_319_PUC-2, M72/2_310), } \\
\text { AODC (M72/2_309_PUC-36), }\end{array}$ \\
\hline St. 2 & $\begin{array}{l}\text { Plateau: geographical } \\
\text { center of the DMV }\end{array}$ & $\begin{array}{l}44^{\circ} 16.95^{\prime} \mathrm{N} \\
34^{\circ} 58.94^{\prime} \mathrm{E}\end{array}$ & $\begin{array}{l}\text { Microsensor measurements (M72/2_309_MICP-2), } \\
\text { SR, AOM (M72/2_270), } \\
\text { geochemical analyses (M72/2_269, M72/2_300), } \\
\text { AODC (M72/2_270), }\end{array}$ \\
\hline St. 3 & Northern edge & $\begin{array}{l}44^{\circ} 17.14^{\prime} \mathrm{N} \\
34^{\circ} 58.84^{\prime} \mathrm{E}\end{array}$ & $\begin{array}{l}\text { Microsensor measurements (M72/2_309_MICP-3), } \\
\text { geochemical analyses (M72/2_319_PUC-43) }\end{array}$ \\
\hline St. 4 & Plateau & $\begin{array}{l}44^{\circ} 17.12^{\prime} \mathrm{N} \\
34^{\circ} 58.85^{\prime} \mathrm{E}\end{array}$ & Microsensor measurements (M72/2_309_MICP-4) \\
\hline St. 5 & Plateau & $\begin{array}{l}44^{\circ} 17.10^{\prime} \mathrm{N} \\
34^{\circ} 58.86^{\prime} \mathrm{E}\end{array}$ & Microsensor measurements (M72/2_309_MICP-5) \\
\hline St. 6 & Plateau & $\begin{array}{l}44^{\circ} 17.06^{\prime} \mathrm{N} \\
34^{\circ} 58.87^{\prime} \mathrm{E}\end{array}$ & Microsensor measurements (M72/2_309_MICP-6) \\
\hline St. 7 & Plateau & $\begin{array}{l}44^{\circ} 17.04^{\prime} \mathrm{N} \\
34^{\circ} 58.88^{\prime} \mathrm{E}\end{array}$ & Microsensor measurements (M72/2_309_MICP-7) \\
\hline St. 8 & Western edge & $\begin{array}{l}44^{\circ} 16.97^{\prime} \mathrm{N} \\
34^{\circ} 58.59^{\prime} \mathrm{E}\end{array}$ & $\begin{array}{l}\text { SR, AOM (M72/2_282_PUC-26, -67), } \\
\text { geochemical analyses (M72/2_282_PUC-27) }\end{array}$ \\
\hline St. 9 & North of DMV & $\begin{array}{l}44^{\circ} 17.26^{\prime} \mathrm{N} \\
34^{\circ} 58.98^{\prime} \mathrm{E}\end{array}$ & $\begin{array}{l}\text { SR, AOM (M72/2_280), } \\
\text { geochemical analyses (M72/2_279, M72/2_314), } \\
\text { AODC (M72/2_280) }\end{array}$ \\
\hline St. 10 & South of DMV & $\begin{array}{l}44^{\circ} 16.58^{\prime} \mathrm{N} \\
34^{\circ} 58.64^{\prime} \mathrm{E}\end{array}$ & $\begin{array}{l}\text { SR, AOM (M72/2_291), } \\
\text { geochemical analyses (M72/2_291, M72/2_306) } \\
\text { AODC (M72/2_291) }\end{array}$ \\
\hline
\end{tabular}

ples of the enclosed bottom water were taken with syringes after pre-programmed time intervals. The total deployment time of the benthic chamber was $8 \mathrm{~h}$. After retrieval of the chamber module, subsamples of each water sample were immediately fixed in $\mathrm{ZnAc}(2 \%)$ for chloride analyses ( $1 \mathrm{~mL}$ sample in $0.5 \mathrm{~mL} \mathrm{ZnAc}$ ), stored in gas-tight, headspace-free sealed glass vials for methane concentration measurements (Kvenvolden and McDonald, 1986), or frozen for nutrient analyses. Nutrients were measured with a Skalar Continuous-Flow Analyzer according to the method of Grasshoff et al. (1983). Concentrations of chloride were measured with non-suppressed ion-chromatography (Waters 510 HPLC Pump; Waters IC-Pak $50 \times 4.6 \mathrm{~mm}$ anion exchange column; Waters 430 Conductivity detector). Methane was measured in the headspace of the glass vial after heating to $60{ }^{\circ} \mathrm{C}$ for $30 \mathrm{~min}$ (ODP Leg 201 Shipboard Scientific Party, 2003) with a gas chromatograph (5890A, Hewlett Packard) coupled to a flame ionization detector (HP 5890 GC-FID). A GFT-Poropak-Q column (6 ft., $80 / 100)$ was installed for the chromatographic separation using the following temperature program: initial oven temperature: $40^{\circ} \mathrm{C}$, hold for $1 \mathrm{~min}$, heating rate of $20^{\circ} \mathrm{C} \mathrm{min}{ }^{-1}$ to $200^{\circ} \mathrm{C}(1 \mathrm{~min})$. The precision of the gas chromatography measurements was $\pm 5 \%$.

Fluxes of methane, chloride, and ammonium were calculated from the linear increase of the constituents in the enclosed water volume over time. As methane and chloride fluxes were rather constant during the entire deployment, the linear increase over $8 \mathrm{~h}$ of deployment was considered, in the case of ammonium, only the linear increase over the first $4 \mathrm{~h}$ was used for the calculation of the flux.

\subsection{Bottom water and sediment pore-water analyses}

Seawater was sampled at defined spots $10 \mathrm{~cm}$ above the seafloor with the ROV fluid sampling system KIPS (Schmidt et al., 2007). The samples were enclosed in PFA (perfluoralkoxy) flasks, where they stayed during the dive. The $\mathrm{pH}$ in the water samples was measured immediately after surfacing of the ROV. Subsamples for nutrient concentrations analyses were treated and measured as described above.

For analyses of sediment solutes either push cores or TV-MUC cores were taken at St. 1, 2, 3, 8, 9 and 10 (Fig. 1). Pore water was extracted from the sediment with Rhizons (type: CSS, Rhizosphere Research Products, filter capacity of $0.1 \mu \mathrm{m}$ ), described in detail elsewhere (SeebergElverfeldt et al., 2005; Dickens et al., 2007; Lichtschlag et al., 2010). To allow Rhizon insertion, holes were drilled in the core liners at depth intervals of $1 \mathrm{~cm}$ and sealed with diffusion-tight PVC tape before sampling to prevent loss of gasses and ions from the core. After retrieval the tape was still firmly adhering to the core liner and intrusion of seawater by loosening of the sealing can be excluded. The 

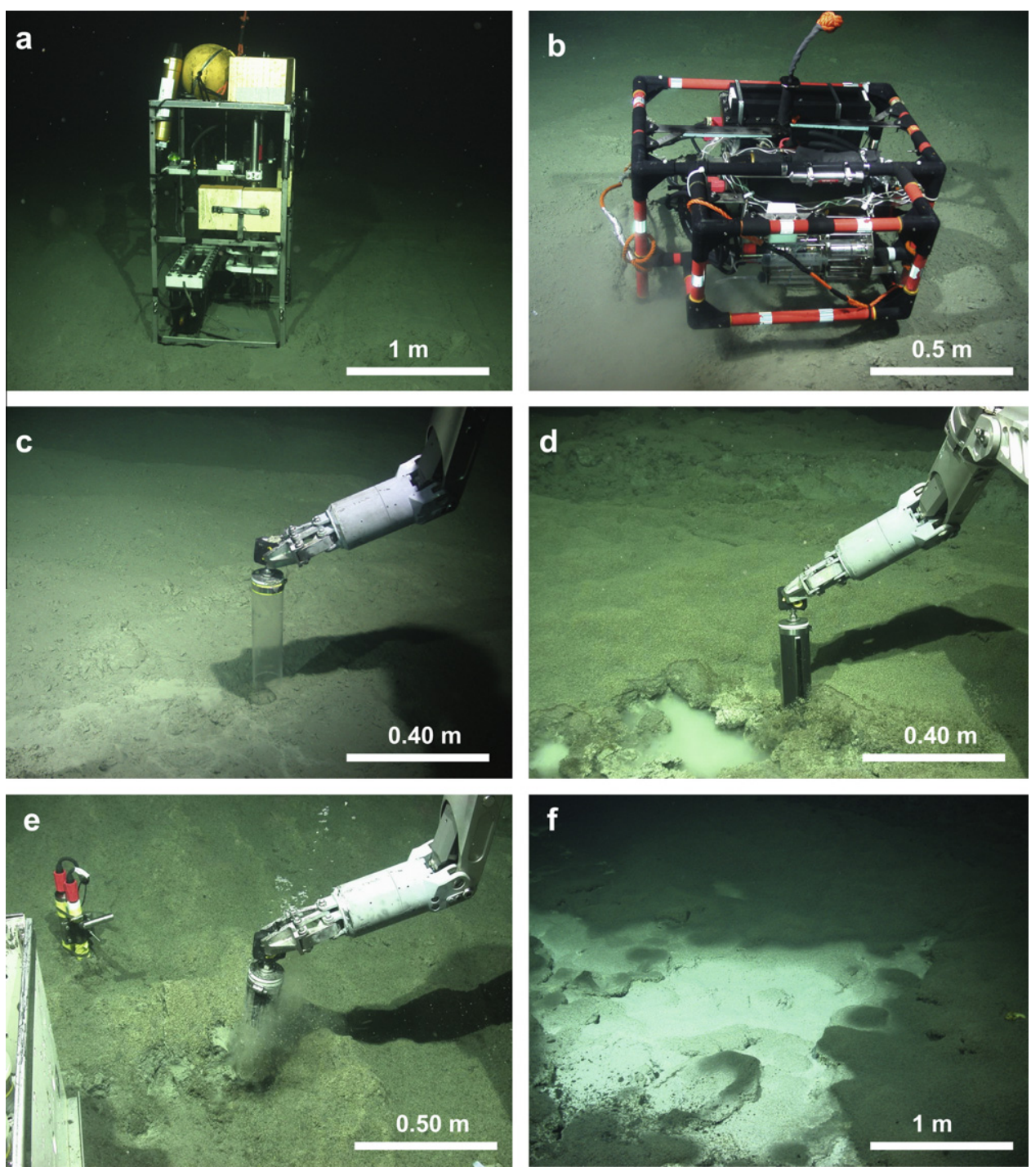

Fig. 2. (a) Microprofiler measurements, (b) benthic chamber module deployment, and (c) sediment sampling at the summit lacking the fluffy layer on top of the sediment; (d) sediment sampling at the plateau with a thick fluffy layer on top of the sediment; (e) gas bubble escape during coring at the geographical center (plateau); (f) white patch at the western edge. Source: ROV Quest 4000 (MARUM, Bremen).

wet Rhizons were horizontally inserted into each sediment horizon through the tape covering the predrilled holes and pore water was extracted gently by manually applying an under-pressure with a syringe. Only $3-4 \mathrm{~mL}$ were extracted per Rhizon to avoid a mixing of pore waters across the different horizons. The initial half $\mathrm{mL}$ of the extracted pore water was discarded to avoid dilution with MQ water in which the Rhizons were stored. Pore-water subsamples for dissolved inorganic carbon (DIC) were quickly transferred into glass vials $(2 \mathrm{~mL})$ leaving no headspace and poisoned with $20 \mu \mathrm{L}$ saturated $\mathrm{HgCl}_{2}$ for concentration measurements or sterile filtered for determination of the DIC isotopic composition. Further subsamples $(0.5 \mathrm{~mL})$ were transferred into plastic vials with $0.5 \mathrm{~mL} \mathrm{ZnAc}(2 \%)$ for sulfate, chloride, and sulfide determination. Sulfate and chloride were measured with non-suppressed ion-chromatography as described above. The photometric methylene blue method (Cline, 1969) was used to measure the sulfide concentration. DIC concentrations were measured with a conductivity detector (VWR scientific, model 1054) with $30 \mathrm{mmol} \mathrm{L}^{-1} \mathrm{HCl}$ and $10 \mathrm{mmol} \mathrm{L}^{-1} \mathrm{NaOH}$ as eluent according to the method of Hall and Aller (1992).

For methane, propane, and ethane analyses sediments were sampled with a gravity corer at the same stations as the TV-MUCS and the push cores. For ex situ concentration measurements $3 \mathrm{~mL}$ wet sediment samples were taken in cut-off syringes, extruded into $20-\mathrm{mL}$ vials and closed gas tight. After heating to $60{ }^{\circ} \mathrm{C}$ for $30 \mathrm{~min}, 100 \mu \mathrm{L}$ subsamples were taken from the gas phase with gas tight syringes and measured as described above. For onshore isotopic analysis of the methane, $5 \mathrm{~mL}$ headspace gas were transferred into vials filled with saturated $\mathrm{NaCl}$-solution using gas tight syringes and volume-volume exchange with hypodermic needles, and stored upside-down. However, all cores 
from the DMV plateau showed a strong degassing, causing artifacts in the ex situ gas distribution. Autoclave coring tools for the determination of in situ gas concentrations were not available during our cruise leg, but total in situ methane concentrations were determined a month later at the same sites (M72/3; Feseker et al., 2009). The methane hydrate content of the central plateau sediments was as high as $1.7 \mathrm{mmol} \mathrm{cm} \mathrm{cm}^{-3}$. The equilibrium concentrations for methane in hydrate and dissolved in pore water for the different temperature and salinity regimes in the sediment are discussed in Wallmann et al. (2006) and Feseker et al. (2009), and range between $118 \mathrm{mmol} \mathrm{CH}_{4} \mathrm{~L}^{-1}$ $\left(16.5^{\circ} \mathrm{C}\right)$ and $85 \mathrm{mmol} \mathrm{CH}_{4} \mathrm{~L}^{-1}\left(10^{\circ} \mathrm{C}\right)$. A conservative estimate of in situ methane concentration in the hydratefree 0-100 cm layer was used by Feseker et al. (2009) with $60 \mathrm{mmol} \mathrm{CH}_{4} \mathrm{~L}^{-1}$, assuming the absence of free gas in the surface layer. However, as we did observe the presence of free gas in the summit and plateau surface sediments during sampling, and a high fluid-flow velocity restricting the zone of mixing with seawater to the top centimeter (de Beer et al. 2006), we assume a range of in situ concentrations of 85$118 \mathrm{mmol} \mathrm{CH}_{4} \mathrm{~L}^{-1}$ for the DMV surface sediments for further flux estimates.

The DIC isotopic composition was measured with a GasBench automated sampler, interfaced to a Finnigan MAT 251 mass spectrometer. Prior to analysis, a porewater aliquot $(\sim 0.5-1 \mathrm{~mL})$ was flushed with helium 5 times to remove residual $\mathrm{CO}_{2}$ and subsequently acidified with phosphoric acid to allow $\mathrm{CO}_{2}$ extraction. Analyses were calibrated with a known standard (Solnhofen limestone) of defined isotopic value, primary standardization occurred by tank $\mathrm{CO}_{2}$ (purity: 99.995\%). Standard deviation was estimated to be less than $0.1 \%$. The stable carbon isotopic composition of methane was analyzed by gas chromatography-isotope ratio mass spectrometry using a Thermo Finnigan Trace GC ultra coupled to a Thermo Finnigan Deltaplus XP mass spectrometer via a Thermo Finnigan GC Combustion III interface. The GC was equipped with a Supelco Carboxen 1006 Plot fused-silica capillary column (30 $\mathrm{m} \times 0.32 \mathrm{~mm}$ in diameter). The initial oven temperature was set to $40^{\circ} \mathrm{C}$, kept for $4 \mathrm{~min}$, raised by $20-50{ }^{\circ} \mathrm{C} \mathrm{min}-1$ to $240{ }^{\circ} \mathrm{C}$, held for $1 \mathrm{~min}$. Standard deviations were usually less than $1 \%$. Isotope ratios are given in $\delta$-notation relative to the Vienna Peedee Belemnite Standard (V-PDB).

\subsection{Sulfate reduction (SR) and anaerobic methane oxidation (AOM)}

For rate measurements of anaerobic methane oxidation and sulfate reduction sediment samples were retrieved for the whole core injection method (Jørgensen, 1978; Treude et al., 2003). Briefly, push core sediments were vertically sub-sampled with small subcore liners (diameter $=2.5 \mathrm{~cm}$ ). For each sampling station and method 3-4 replicate subcores were used. On board, either $10 \mu \mathrm{L}^{35} \mathrm{SO}_{4}{ }^{2-}(75 \mathrm{kBq}$ activity dissolved in water) or $20 \mu \mathrm{L}^{14} \mathrm{CH}_{4}(1.4 \mathrm{kBq}$ activity dissolved in water) were injected into the subcores in $1 \mathrm{~cm}$ intervals through silicon-sealed holes. The sediment was incubated in the dark for $12 \mathrm{~h}$ at in situ temperature and standard pressure. Samples were digested and analyzed as described before (Kallmeyer et al., 2004; Treude et al., 2003). Measurements were carried out on sediment samples from St. 1, 2, 8, 9 and 10.

\subsection{Acridine orange direct counts (AODC)}

Sediments were sliced in $1 \mathrm{~cm}$ intervals, fixed in formalin/ seawater, and the total number of microbial cells present in $1 \mathrm{~cm}^{3}$ sediment was determined with acridine orange direct counts (AODC) via epifluoresence microscopy (Meyer-Reil, 1983; Boetius and Lochte, 1996). Cell counts include only single cells and no aggregates.

\section{RESULTS}

\subsection{Site and sediment description}

The video transects showed spatial differences in the surface morphology across the DMV (Fig. 2). At the geographical center (St. 2, Fig. 2e) the sediment surface was uneven with small hills (maximal heights of $20 \mathrm{~cm}$ ). As visible by video observation and on retrieved sediments a beige-brown fluffy layer of sedimented detritus of about $1 \mathrm{~cm}$ thickness covered the surface. At the summit (St. 1, Fig. $2 \mathrm{a}-\mathrm{c}$ ) the seafloor was even more hummocky, and ripple-like structures with a wavelength of approximately $50 \mathrm{~cm}$ were present. Here, no fluff layer was observed on top of the seafloor. The seafloor at all other sites of the plateau (St. 4-7) was flat and the fluffy layer was covering the seafloor completely. At the northern (St. 3) and western edge (St. 8) the thickness of the fluffy layer increased to $2 \mathrm{~cm}$. Here, the seabed was again very hummocky and many cracks were observed on the surface.

Sediments retrieved from the site north of the DMV (St. 9) were covered with up to $7 \mathrm{~cm}$ of the fluff. Here, no ROV dives were carried out but samples were recovered with a TV-guided multiple corer. The material forming the fluffy layer comprises of deposits of marine snow often found on top of Black Sea sediments. It was stratified with interspersed brown-green layers separating about $1 \mathrm{~mm}$ thick whitish zones representing the sedimentation of coccolithophorid blooms. Below the fluffy layer the sediment recovered from the DMV was homogeneous over the whole core length, with a dark, olive-green sediment color, a fine-grained sediment texture and the presence of gas bubbles from methane oversaturation after retrieval. From the summit and the plateau of the DMV (between St. 1, 2, 6 and 7) occasionally gas bubbles were released from the sediment upon touching the seafloor with our instruments and samplers (Fig. 2e), indicating that methane was oversaturated in situ. This is related to the high in situ concentrations of dissolved methane. At the northern, western, and southern edge of the DMV video observation showed white patches on the seafloor (Fig. 2f). Microscopy of recovered samples from these white patches showed needle shaped minerals (possibly barite). The white material did not contain sulfide-oxidizing bacteria, which are usually forming conspicuous whitish mats at cold seeps that reside in oxic and suboxic bottom waters. 


\subsection{In situ microsensor measurements and flux calculations}

\subsubsection{Temperature}

The highest sediment temperature gradients of up to $10.2{ }^{\circ} \mathrm{C} \mathrm{m}^{-1}$ were found at the summit of the DMV (St. 1; Fig. $3 \mathrm{~b}$ and c). Temperature of the top $10 \mathrm{~cm}$ seafloor sediment was $9-10{ }^{\circ} \mathrm{C}$ at the summit and $8-9{ }^{\circ} \mathrm{C}$ at the surrounding plateau. The temperature in the water column above the summit was also slightly elevated $\left(+0.1^{\circ} \mathrm{C}\right.$, $5 \mathrm{~cm}$ above the sediment). At St. 7 the sediment temperature gradient was already reduced to $15 \%$ of the value at the summit (Fig. 3d) and decreased further towards the northern edge. The temperature gradient at the geographical center (St. 2) was $1.2^{\circ} \mathrm{C} \mathrm{m}^{-1}$, in between those of St. 6 and St. 5. At the outer edge (Fig. 3h) the gradient was only $2 \%$ of that of the summit. Sediment temperature gradients are summarized in Table 2.

\subsubsection{Sulfide}

Sulfide concentrations were the lowest in sediments of the summit of the DMV (St. 1, Fig. 3). The stations at the edge (St. 3) and plateau (St. 2, 4-7) showed elevated concentrations of sulfide in the sediment indicating local production. Neither the sulfide depth distributions, nor the concentration maxima of sulfide showed a gradual succession with distance from the summit, in contrast to the temperature gradients. Interestingly, at most sites two sulfide peaks were found in the sediment: one at the sediment-water interface and a second one at $3-15 \mathrm{~cm}$ bsf (below surface). In several profiles the sulfide steadily decreased with sediment depth below the second concentration maximum. The peaks indicate zones of net production separated by a sulfide sink. From the sum of the diffusive fluxes below and above these zones, an average volumetric consumption rate of $1300 \mathrm{mmol} \mathrm{m} \mathrm{m}^{-3} \mathrm{~d}^{-1}$ was calculated from profiles with dips. The time needed for leveling of the two concentration maxima into a straight line by diffusion, was modeled using a one-dimensional COMSOL multiphysics modeling suite, resulting in an leveling of the two sulfide peaks in the order of days.

Sulfide fluxes are calculated from the gradients and are summarized in Table 2. Sulfide fluxes are displayed as (I) fluxes calculated from the DBL and thus representing the sulfide that is released from the sediment into the water column and (II) upward directed sulfide fluxes of the second, deeper located sulfide peak. The DBL sulfide fluxes (I) showed an increase along the transect from the summit to the northern edge. The upward sulfide fluxes calculated from the gradients in the subsurface sediment (II) were substantially lower with lowest fluxes at the summit, intermediate fluxes in the plateau area and highest fluxes at the edge. Hence, most sulfide emitted was produced close to the sediment seawater interface.

Sulfide consumption in these highly reduced sediments is negligible, which can be deduced from comparison of net and gross sulfate reduction (measured SR rates vs. sedimentary sulfide fluxes; Table 2). The diffusive flux downward equals the advective flux upward. Assuming steady state the fluid velocity can then be calculated from the shape of the sulfide profiles below the lower sulfide peak (de Beer et al., 2006):

$c_{x}=c_{0} e^{-\frac{v x}{D_{\text {sed }}}}$,

where $c_{x}$ is the solute concentration at sediment depth $x, c_{0}$ is the concentration at the source (in this case the maximal concentration of the lower sulfide peak), $v$ is the upflow velocity $\left(\mathrm{m} \mathrm{yr}^{-1}\right)$ and $D_{\text {Sed }}$ is as defined in Eq. (5). Modeling of the fluid-upflow velocities from sulfide profiles was possible at St. 2 and 3. The upflow velocities obtained by this modeling approach are displayed in Table 2. To estimate the effect of fluid flow on the sulfide fluxes, which in Table 2 are displayed as diffusive fluxes $\left(J_{\text {diff }}\right)$, the total flux $\left(J_{\text {tot }}\right)$ was calculated as described previously (de Beer et al., 2006):

$J_{\text {tot }}=J_{\text {diff }}+J_{\text {adv }}$,

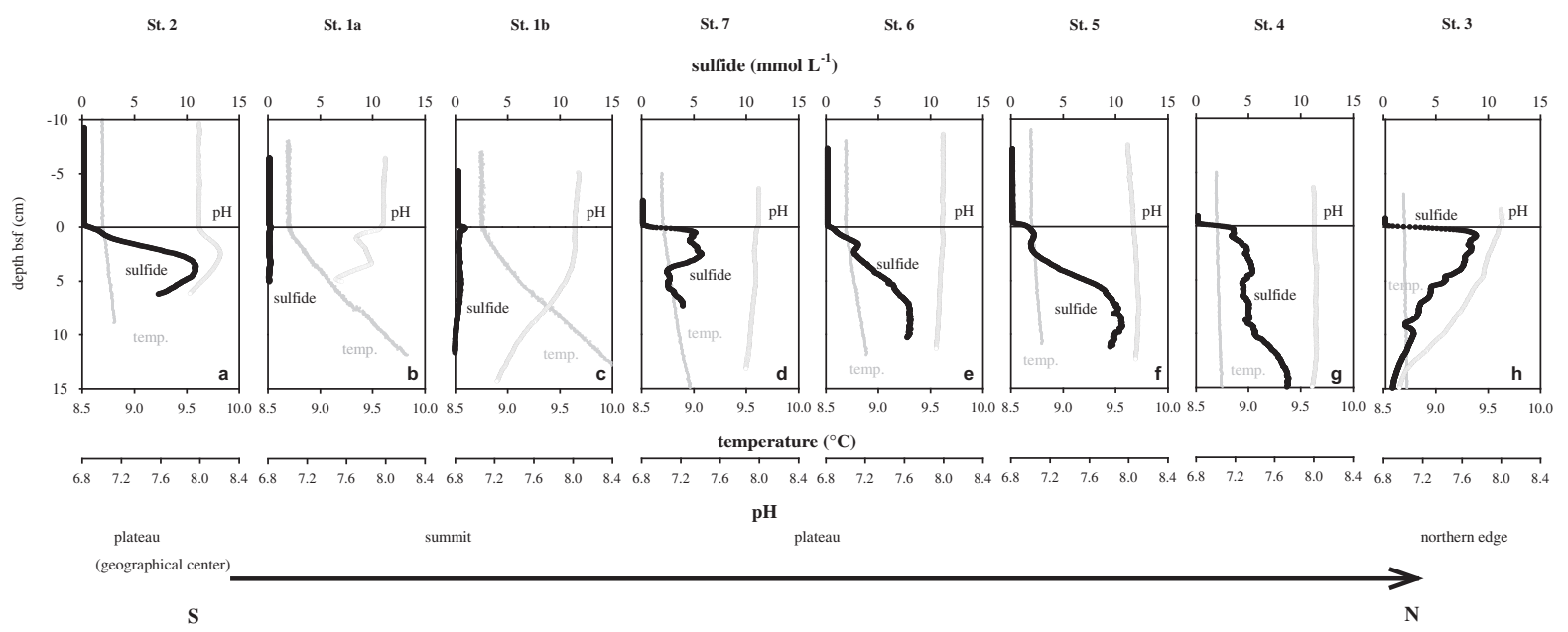

Fig. 3. (a-h) High-resolution in situ microsensor profiles of sulfide $\left(\mathrm{H}_{2} \mathrm{~S}+\mathrm{HS}^{-}+\mathrm{S}^{2-}\right)$, $\mathrm{pH}$ and temperature. Graphs are arranged in geographical order from the most southward station (geographical center, St. 2), crossing the summit (St. 1a, 1b), the plateau north of the summit (St. 7-4), and ending at the northern edge (St. 3). Sulfide profiles from St. 1 to St. 6 are averages of results from three different sensors. At St. 7 only two sensors worked. Except for St. 1 only one of the two pH sensors was functional. 
Table 2

Results from in situ microsensor measurements and ex situ AOM and SR rate measurements. For the sulfide fluxes averages are given with standard deviation (SD) wherever possible (St. 1-6: $n=3$; St. 7: $n=2$ ); for rate measurements $n=3$; rates are integrated over $0-10 \mathrm{~cm}$ sediment depth. n.d. = not determined. DBL: diffusive boundary layer.

\begin{tabular}{|c|c|c|c|c|c|c|c|c|c|c|}
\hline & $\begin{array}{l}\text { St. } 1 \mathrm{a} / \mathrm{b} \\
\text { summit }\end{array}$ & $\begin{array}{l}\text { St. } 2 \text { plateau } \\
\text { (geographical } \\
\text { center) }\end{array}$ & $\begin{array}{l}\text { St. } 3 \\
\text { northern } \\
\text { edge }\end{array}$ & $\begin{array}{l}\text { St. } 4 \\
\text { plateau }\end{array}$ & $\begin{array}{l}\text { St. } 5 \\
\text { plateau }\end{array}$ & $\begin{array}{l}\text { St. } 6 \\
\text { plateau }\end{array}$ & $\begin{array}{l}\text { St. } 7 \\
\text { plateau }\end{array}$ & $\begin{array}{l}\text { St. } 8 \\
\text { western } \\
\text { edge }\end{array}$ & $\begin{array}{l}\text { St. } 9 \\
\text { north } \\
\text { of DMV }\end{array}$ & $\begin{array}{l}\text { St. } 10 \\
\text { south } \\
\text { of DMV }\end{array}$ \\
\hline $\begin{array}{l}\text { Temperature } \\
\text { gradient }\left({ }^{\circ} \mathrm{C} \mathrm{m}^{-1}\right)\end{array}$ & $9.7 / 10.2$ & 1.2 & 0.2 & 0.3 & 0.8 & 1.7 & 1.7 & n.d. & n.d. & n.d. \\
\hline $\begin{array}{l}\text { Fluid upflow from } \\
\text { sulfide profile }\left(\mathrm{m} \mathrm{yr}^{-1}\right)\end{array}$ & n.d. & 0.3 & 0.3 & n.d. & n.d. & n.d. & n.d. & n.d. & n.d. & n.d. \\
\hline $\begin{array}{l}\text { (I) Diffusive sulfide } \\
\text { flux across DBL } \\
\left(\mathrm{mmol} \mathrm{m}{ }^{-2} \mathrm{~d}^{-1}\right) \pm \mathrm{SD}\end{array}$ & $10 \pm 8$ & $27 \pm 17$ & $\begin{array}{l}105 \pm 128 \\
\text { (sulfide } \\
\text { flux I+II) }\end{array}$ & $74 \pm 45$ & $45 \pm 29$ & $15 \pm 16$ & $37 \pm 1$ & n.d. & n.d. & n.d. \\
\hline $\begin{array}{l}\text { (II) Upward directed, } \\
\text { diffusive sulfide flux of } \\
\text { second sulfide peak } \\
\left(\mathrm{mmol} \mathrm{m}^{-2} \mathrm{~d}^{-1}\right) \pm \mathrm{SD}\end{array}$ & $0.7 \pm 0.5 / 0.3$ & $18 \pm 4$ & $\begin{array}{l}\text { See }(\mathrm{I}) \\
\text { sulfide } \\
\text { flux across } \\
\text { the DBL }\end{array}$ & $5 \pm 2$ & $10 \pm 1$ & $7 \pm 2$ & $3 \pm 1$ & n.d. & n.d. & n.d. \\
\hline $\begin{array}{l}\text { Depth-integrated sulfate } \\
\text { reduction rates (ex situ) } \\
\left(\mathrm{mmol} \mathrm{m}^{-2} \mathrm{~d}^{-1}\right) \pm \mathrm{SD}\end{array}$ & $0.05 \pm 0$ & $19.8 \pm 5.7$ & n.d. & n.d. & n.d. & n.d. & n.d. & $108 \pm 38$ & $0.2 \pm 0$ & $0.2 \pm 0.1$ \\
\hline $\begin{array}{l}\text { Depth-integrated methane } \\
\text { oxidation rates (ex situ) } \\
\left(\mathrm{mmol} \mathrm{m}^{-2} \mathrm{~d}^{-1}\right) \pm \mathrm{SD}\end{array}$ & $0.07 \pm 0.1$ & $9.1 \pm 6$ & n.d. & n.d. & n.d & n.d. & n.d. & $11.2 \pm 9.6$ & $<0.01$ & $0.2 \pm 0.1$ \\
\hline
\end{tabular}

where $J_{\text {diff }}$ is defined in Eq. (4) and $J_{\text {adv }}$ is the advective flux $\left(v \times c_{x}\right)$. The interfacial fluxes appeared to be hardly influenced by the upflow velocities obtained with Eq. (6). Less than $5 \%$ of the total sulfide flux across the DBL was due to the advectional term. With the upflow velocity calculated in Eq. (6), the total efflux from the second peak was $25 \%$ higher at the geographical center (St. 2). As this is in the range of uncertainty inherent to our approach, in the further discussion the diffusive fluxes are considered accurate.

\subsection{3. $p H$}

At one deployment at the DMV summit (St. 1a) both $\mathrm{pH}$ sensors recorded a very distinct profile with a dip just below the sediment surface followed by a peak at $3.5 \mathrm{~cm}$ bsf, and a gradual decline below this depth (Fig. 3b). The replicate measurement at the summit (St. 1b, about $15 \mathrm{~m}$ away from the first one), showed a gradual decline of $\mathrm{pH}$ (Fig. 3c). At the plateau area north of the summit the $\mathrm{pH}$ was more or less constant with depth (Fig. 3d-g). The $\mathrm{pH}$ profiles at the edge (Fig. 3h) showed a steady decrease with depth with a similar profile as in St. 1b. At the geographical center (St. 2) there was a clear and strong peak in $\mathrm{pH}$ at a depth of $2 \mathrm{~cm}$ (Fig. 3a).

\subsection{Benthic chamber measurements}

The summit of the DMV emits large amounts of methane, ammonium, and chloride, as indicated by their concentration increase with time in the benthic chamber (Fig. 4; Table 3). Using the effluxes and pore-water concentrations of these solutes, an upflow velocity of the mud volcano fluid between 1 and $2.8 \mathrm{~m} \mathrm{yr}^{-1}$ was estimated (Table 3 ). This procedure for estimating fluid-flow rates requires some assumptions: no consumption of the solutes in the sediment, no enhanced solute exchange during the chamber placement, and a constant efflux. Pushing a benthic chamber into sediment may cause an enhanced release of constituents from the pore water into the chamber. However, the results from our deployment revealed that the chloride and ammonium concentrations, which are significantly enriched in DMV pore waters, showed reasonable values close to Black Sea bottom water concentrations shortly $(1 \mathrm{~h})$ after the chamber was placed and a linear increase with time, indicating that no significant artificial enrichment in the enclosed water body took place. Also, no visual gas ebullition was observed during the placement of the chamber. However, calculating the methane concentration at time zero from the linear increase in the chamber, the methane concentration was around $250 \mu \mathrm{M}$ in the water above the summit, compared to $>85 \mathrm{mmol} \mathrm{L}^{-1}$ in the sediment pore water (Wallmann et al., 2006).

The fluid flow calculated from the chloride, methane, and ammonium increase should be similar over the entire incubation, which is not the case, especially for ammonium. Taking only the first linear ( $0-4 \mathrm{~h}$ of incubation) ammonium increase into account results in a fluid-flow velocity of $1 \mathrm{~m} \mathrm{yr}^{-1}$. The process for this difference in the ammonium increase compared to the increase of the other constituents can unfortunately not be deduced from our set of data. As chloride is the most conservative constituent we assume the upflow based on chloride as most reliable, thus the fluid flow at the DMV will be maximally $2.8 \mathrm{~m} \mathrm{yr}^{-1}$.

\subsection{Geochemistry of bottom water and pore water}

The $\mathrm{pH}$ of the Black Sea water at $10 \mathrm{~cm}$ above the seafloor of the DMV was 8.0. No nitrate or nitrite was found. Ammonium and chloride were equally high in the water above the summit and the geographical center (90 and $315 \mu \mathrm{mol} \mathrm{L}^{-1}$, respectively). At the northern edge of the 

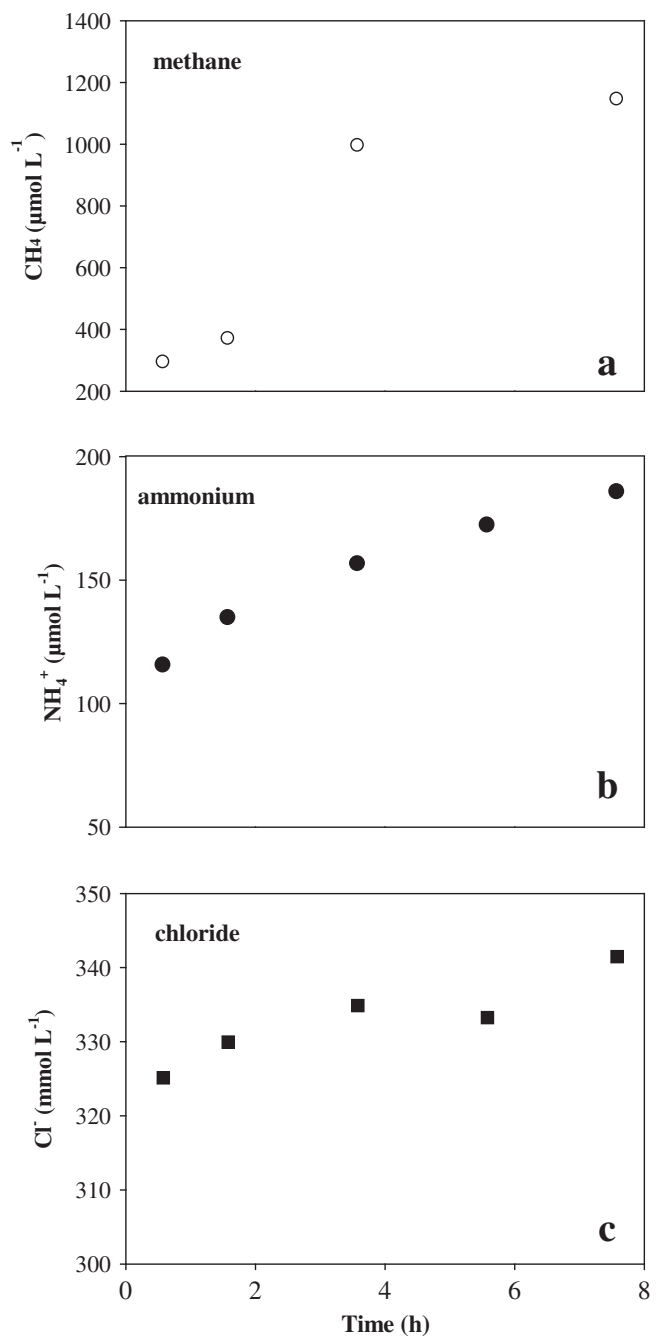

Fig. 4. Results from analyses of (a) methane, (b) ammonium, and (c) chloride in water collected inside the benthic chamber during the $8 \mathrm{~h}$ deployment at the summit. Fluxes are calculated from the linear increase of the compounds inside the chamber.

DMV ammonium values were reduced to half of the amount of the other sites.

Solute distributions in recovered sediment cores differed substantially between the sampling stations. In the core from the summit (St. 1) a strong outgassing was observed after retrieval. In this core sulfate was detected to a depth of up to $10 \mathrm{~cm}$ after retrieval (Fig. 5a). In the less gaseous geographical center (St. 2) sulfate was found only to a depth of $5 \mathrm{~cm}$ (Fig. $5 \mathrm{~g}$ ). Despite the small-scale variability it can be concluded that the surface pore water of DMV was depleted in sulfate, and elevated in chloride and DIC (Fig. 5). Outside the volcano (reference St. 9) concentrations of sulfate, chloride, sulfide, DIC, and the isotopic composition of the DIC were almost constant with sediment depth $(0-12 \mathrm{~cm})$, and close to seawater values. The sulfide concentrations (Fig. $5 \mathrm{c}, \mathrm{i}, \mathrm{o}, \mathrm{s}$ ) in the retrieved cores were always lower than measured in situ with the microprofiler. This might be an effect from core retrieval, which can induce seawater mixing into the sediment and can lead to methane gas formation due to oversaturation during ascent, flushing out concomitant gases like $\mathrm{H}_{2} \mathrm{~S}$. Degassing during core retrieval also affected methane concentrations in the cores. After retrieval all cores from the plateau of the DMV had substantially lost methane from the pore water, and showed concentrations above atmospheric pressure throughout the sediment core $\left(>1.4 \mathrm{mmol} \mathrm{L}^{-1}\right)$. Concentrations of ethane and propane in the sediment were three to four orders of magnitude lower than methane concentrations, similar to previously published concentrations (Blinova et al., 2003; Feseker et al. 2009). The $\delta^{13} \mathrm{C}$ signature of methane retrieved from the summit of the DMV was around $-60 \%$ V-PDB. The DIC carbon isotope signature was similar over the whole sediment cores $(+8 \%$ o V-PDB, Fig. 5d), and the same as found in several meters depth (data from gravity core 310 , not shown), thus conversion of methane to DIC is slow at the summit compared to the transport of DIC from the subsurface. At the geographical center the DIC concentration increased to maximally $17 \mathrm{mmol} \mathrm{L}^{-1}$ in $10 \mathrm{~cm}$ depth. Here the lowest DIC $\delta^{13} \mathrm{C}$ value $(-30 \%$ V-PDB) was found $2 \mathrm{~cm}$ below the sediment surface, and the signature became less depleted with depth (Fig. 5j). Also at the edge stations the DIC concentrations increased with depth (Fig. 5p and t). At the reference site (St. 9) outside the DMV the DIC $\delta^{13} \mathrm{C}$ signature was constant over the upper $10 \mathrm{~cm}$ sediment depth (Fig. 5z), and methane concentrations were $<0.1 \mathrm{mmol} \mathrm{L}^{-1}$ in the top $100 \mathrm{~cm}$ (data not shown).

\subsection{Rates of sulfate reduction (SR) and anaerobic oxidation of methane (AOM)}

Depth-integrated rates $(0-10 \mathrm{~cm})$ of SR and AOM are summarized in Table 2. At the summit (St. 1, Fig. 5e) SR and AOM were very low in the upper $10 \mathrm{~cm}$, but above detection limit. In the geographical center of the DMV (St. 2, Fig. 5k) SR reached $20 \mathrm{mmol} \mathrm{m}^{-2} \mathrm{~d}^{-1}$. The highest

Table 3

Results from the deployment of the benthic chamber at the summit of the DMV (St. 1). The upflow was calculated from the flux of solutes into the chamber and the solute fluid concentrations.

\begin{tabular}{lllll}
\hline & Chloride & Ammonium & Methane & Methane \\
\hline Total emission $\left(\mathrm{mmol} \mathrm{m}^{-2} \mathrm{~d}^{-1}\right)$ & $3.6 \times 10^{3}$ & 92 & 458 & 458 \\
Concentration in mud volcano fluid $\left(\mathrm{mmol} \mathrm{L}^{-1}\right)$ & 810 & $20^{*}$ & $85^{* *}$ & $118^{* * *}$ \\
Upflow $\left(\mathrm{m} \mathrm{yr}^{-1}\right)$ & 2.8 & 1.0 & 1.8 & 1.3 \\
\hline
\end{tabular}

*Ammonium concentration of the fluid as in Aloisi et al. (2004); methane concentration at the summit at equilibrium at ambient salinity, temperature, and pressure as in **Wallmann et al. (2006) and in ***Feseker et al. (2009); it was assumed that no methane was consumed in the summit sediments (see Section 4). 


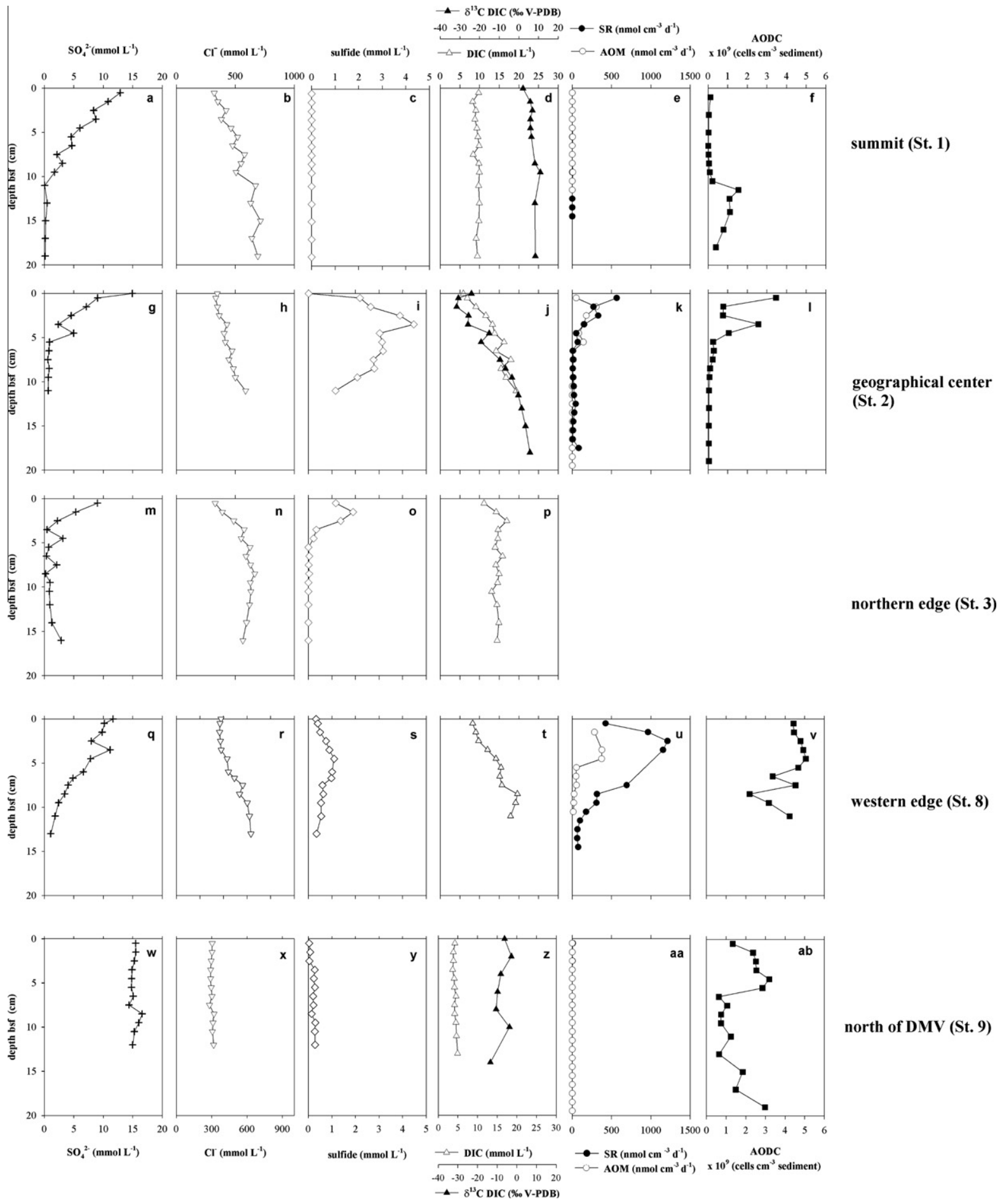

Fig. 5. Pore-water characteristics, anaerobic methane oxidation (AOM) and sulfate reduction (SR) rates, and acridine orange direct counts of cells in the sediments (AODC) of the DMV sampling stations.

SR rate was detected directly at the seafloor-water interface, where it exceeded AOM significantly. Below the first $\mathrm{cm}, \mathrm{AOM}$ and SR were similar. AOM rates at the western edge (St. 8) were similar to results from the geographical center, but SR exceeded AOM considerably (Fig. 5u). Ex- cept the summit, all sites on the plateau of the DMV showed considerably higher SR and AOM rates than the sites outside the DMV (Table 2, Fig. 5). Outside the mud volcano, integrated SR rates were only $0.2-1 \%$ of those on the plateau, but slightly higher than those of the summit. 


\subsection{AODC counts}

Cell counts from the summit showed an unusual depletion in cells in the first $10 \mathrm{~cm}$ of the sediment with values of on average $10^{7}$ cells per $\mathrm{cm}^{3}$ sediment (Fig. 5f). This is one to two orders of magnitude lower than in the same sediment depth at the sites north and south of the DMV (Fig. 5ab). Below the depth of $10 \mathrm{~cm}$ the amount of cells in sediments from the summit increased to $10^{9}$ cells per $\mathrm{cm}^{3}$ sediment. At the geographical center the number decreased with depth from $10^{9}$ cells per $\mathrm{cm}^{3}$ sediment at the sediment surface to $10^{7}$ cells per $\mathrm{cm}^{3}$ sediment in $18 \mathrm{~cm}$ depth (Fig. 51). Numbers of cells were constantly high over the upper $10 \mathrm{~cm}$ at the western edge (St. 8). These cell counts always comprise only single cells and not aggregated microbial cells.

\section{DISCUSSION}

\subsection{Patterns of fluid flow and methane flux}

The Dvurechenskii mud volcano has the shape of a flat mud pie with a steep outer edge, and consists of a warm inner mud and fluid-flow channel with a decreasing temperature gradient to the outside (Feseker et al., 2009). Previous ex situ biogeochemical measurements at the DMV indicated a radial zonation of the DMV with highest fluid upflow and most intense anaerobic oxidation of methane in the central part, gradually decreasing towards the outer zone (Wallmann et al., 2006). During our investigations we studied the geochemical structure of the DMV with in situ tools to circumvent artifacts during recovery such as disturbances by degassing of cores. The in situ analyses and higher sampling resolution of our study revealed a more complex distribution and relationship of fluid flow and microbial methane and sulfur turnover than previously observed (Bohrmann et al., 2003; Wallmann et al., 2006). This may reflect temporal and spatial changes in volcanic activity. Combining detailed bathymetry and temperature probing, we found a hotspot of fluid flow and mud transport, associated with a small elevation (summit) north of the geographical center of the DMV. This area is likely the position of the methane flare previously reported (Greinert et al., 2006) as the sediment was enriched with methane, which sometimes even resulted in gas ebullition after local disturbances of the seafloor during sampling. Fluid-flow velocity from this methane-laden seafloor measured with the benthic chamber exhibited rates of maximally $2.8 \mathrm{~m} \mathrm{yr}^{-1}$ for this area. Outside the summit, at the geographical center (St. 2) and edge (St. 3), we calculated a fluid flow of $0.3 \mathrm{~m} \mathrm{yr}^{-1}$ from the lower peak of the in situ sulfide profile, similar to velocities previously observed in this area (Aloisi et al., 2004; Wallmann et al., 2006). Although the fluid-upflow velocity was similar as in the geographical center, the temperature gradient was substantially lower at the edge than in all other zones of the DMV (Table 2). This may indicate different sources for mud volcano fluids, which also could lead to the formation of the white patches on top of the sediment of the outer edge, consisting of mineral precipitations (presumably barite) and not of bacterial mats as previously thought (Bohrmann et al., 2003).

Fluid-flow rates have been quantified only at a low number of deep-sea mud volcanoes worldwide (Table 4). Our results indicate medium advective upflow for the DMV compared to other mud volcanoes. Generally, for fluid-flow calculations the assumption of steady state is made. However, mud volcanoes are spatially heterogeneous, temporally variable geo-systems and the temporal dynamics of fluid-flow velocities remain unknown due to the lack of long-term observations.

\subsection{Factors controlling methane consumption and sulfide production}

Most mud volcanoes release methane in dissolved and gaseous phases. At the DMV we did not find active gas vents, but observed the release of gaseous methane upon disturbances of the seafloor such as the touch down of the ROV or coring (Fig. 2e). Measuring emission of dissolved methane in situ with the benthic chamber at the summit of the DMV resulted in an estimate of an emission rate of dissolved methane of $458 \mathrm{mmol} \mathrm{m}^{-2} \mathrm{~d}^{-1}$. This seepage rate is in the upper range of methane emission rates reported from other cold seeps, e.g. $<1 \mathrm{mmol} \mathrm{m}^{-2} \mathrm{~d}^{-1}$ at the Captain Arutyunov mud volcano (Sommer et al., 2009), $15 \mathrm{mmol} \mathrm{m}^{-2} \mathrm{~d}^{-1}$ off the coast of Costa Rica (Mau et al., 2006), or maximally $100 \mathrm{mmol} \mathrm{m}^{-2} \mathrm{~d}^{-1}$ at Hydrate Ridge (Torres et al., 2002).

Table 4

Compilation of upflow velocities from deep-sea mud volcanoes (worldwide).

\begin{tabular}{|c|c|c|}
\hline Location & $\begin{array}{l}\text { Upflow velocity } \\
\left(\mathrm{m} \mathrm{yr}^{-1}\right)\end{array}$ & Reference \\
\hline Håkon Mosby Mud Volcano (Barents Sea) & $0.3-6$ & de Beer et al. (2006) \\
\hline $\begin{array}{l}\text { Mud volcanoes in the Olimpi Mud Volcano field and the Anaximander } \\
\text { mountains (Eastern Mediterranean) }\end{array}$ & $0.03-0.5$ & Haese et al. $(2003,2006)$ \\
\hline Costa Rica Mud mounds & $0.1-3$ & $\begin{array}{l}\text { Hensen et al. (2004), Linke et al. } \\
(2005)\end{array}$ \\
\hline Mud volcanoes off Barbados & $0.1-1.3$ & Henry et al. (1996) \\
\hline Chefren mud volcano (Eastern Mediterranean off the coast of Egypt) & $0.5-15$ & Omoregie et al. (2008) \\
\hline Vodyanitskii mud volcano (Sorokin Trough, Black Sea) & 0.02 & Sahling et al. (2009) \\
\hline Dvurechenskii mud volcano: previous study (Sorokin Trough, Black Sea) & $0.08-0.25$ & $\begin{array}{l}\text { Wallmann et al. (2006), Aloisi } \\
\text { et al. (2004) }\end{array}$ \\
\hline Dvurechenskii mud volcano: this study (Sorokin Trough, Black Sea) & $0.3-1.5$ & This study \\
\hline
\end{tabular}


The high rates of methane emission at rather average fluid-flow velocities are likely explained by relatively low rates of methane consumption in the anoxic Black Sea. Due to the absence of electron acceptors such as oxygen and nitrate, methane consumption was limited to the anaerobic oxidation of methane with sulfate. AOM was virtually absent in the upper $15 \mathrm{~cm}$ of the summit sediment (Fig. 5e). The constant $\delta^{13} \mathrm{C}$ DIC values with depth and low DIC pore-water concentrations (Fig. 5d) confirmed that no methane oxidation occurred in the sediment. A striking difference with other methane seeps was the low number of cells in the upper $10 \mathrm{~cm}$ of the summit sediment, of on average $10^{7}$ cells per $\mathrm{cm}^{3}$ (Fig. $5 \mathrm{f}$ ). In comparison, the sediments of the active Håkon Mosby Mud Volcano area and sediments of Hydrate Ridge contain up to $10^{9}-10^{10}$ cells per $\mathrm{cm}^{3}$ (Knittel et al., 2003; Lösekann et al., 2007). At the reference site north of the DMV 50 times more cells were present than in the upper $10 \mathrm{~cm}$ of the summit sediment (Fig. 5ab). Such a cell number anomaly could have been caused by the extrusion of a 'microbe-depleted' deep subsurface mud package that flowed over the former seafloor, displacing the slowly growing anaerobic methane oxidizers from the surface. A recent mud flow may also explain the absence of the fluffy layer on top of the seafloor, and the temperature anomalies observed (Feseker et al., 2009). Consequently, sulfate reduction was even lower than at the reference station outside the DMV, where the contribution of organoclastic sulfate reduction was around $0.2 \mathrm{mmol} \mathrm{m}^{-2} \mathrm{~d}^{-1}$. Additionally, penetration of sulfate was impeded by high upward flow of sulfate-depleted fluids (de Beer et al., 2006; Niemann et al., 2006). At the high fluidupflow velocity as calculated for the summit (Table 3), in situ sulfate penetration would be restricted to the upper centimeter of the sediment, hence limiting AOM. Fresh mud-flows at certain areas of the DMV was proposed earlier (Bohrmann et al., 2003; Aloisi et al., 2004; Wallmann et al., 2006), and confirm the temporal and spatial dynamics of mud volcano systems.

In contrast to the summit, the surrounding sediments of the DMV plateau were subjected to lower upflow velocities of around $0.3 \mathrm{~m} \mathrm{yr}^{-1}$, associated with significant SR and AOM rates. Interestingly, the AOM and SR rates showed no direct relation to the radially decreasing temperature gradients (Fig. 6). In the plateau and the edge sulfate reduction $\left(20-110 \mathrm{mmol} \mathrm{m}^{-2} \mathrm{~d}^{-1}\right)$ and AOM $\left(10-11 \mathrm{mmol} \mathrm{m}^{-2}\right.$ $\mathrm{d}^{-1}$ ) were similar to the range previously reported from the DMV (Wallmann et al., 2006), or from other mud volcanoes like the Håkon Mosby Mud Volcano (Niemann et al., 2006) and the Kazan Mud Volcano (Haese et al., 2003). DIC concentrations increased considerably with depth and, associated with the peak in methane oxidation, DIC carbon showed the lowest $\delta^{13} \mathrm{C}$ values at $2 \mathrm{~cm}$ bsf $\left(\delta^{13} \mathrm{C}\right.$ DIC: $-30 \%$ V-PDB). This value comprises the isotopic signature of the DIC of the advected mud volcano fluids $(+8 \%$ V-PDB), the DIC diffusing into the sediment from the overlying seawater (Black Sea seawater $\delta^{13} \mathrm{C}$ DIC: $-6.3 \%$ V-PDB, Fry et al., 1991), and the ${ }^{13} \mathrm{C}$ depleted DIC produced in the sediment from methane $\left(\delta^{13} \mathrm{C}\right.$-methane: $-60 \%$ V-PDB) and particular organic matter oxidation $\left(\delta^{13} \mathrm{C}\right.$ POM: $-25.3 \%$ V-PDB, Ivanov and Lein,
2006). Thus with an isotopic composition of $-30 \%$ V-PDB a clear geochemical signature of DIC production from AOM was observed.

At the geographical center SR and AOM rates showed a close relationship between sulfate reduction and methane oxidation (Fig. 5), as commonly expected in a methane-driven system. However, at other sites and especially the edges of the DMV, depth-integrated SR rates exceeded AOM considerably. Sulfate reduction in the upper 10 centimeter outside the DMV stations with higher particular organic matter content (Wallmann et al., 2006) was only $0.2-1 \%$ of the SR found in DMV sediments, thus organoclastic sulfate reduction accounted only for a minor fraction of the total sulfate reduction. Also the measured concentrations of higher hydrocarbons, which would increase non-methane related SR as observed in oily sediments of the Gulf of Mexico (Orcutt et al., 2004), were three to four orders of magnitude lower than that of methane (this study, Blinova et al., 2003; Feseker et al., 2009) and cannot explain the difference between SR and AOM. However, we cannot exclude spatial variations in the flux or deposition of potential electron donors for SR, or that the discrepancy might be an artifact from disturbances of the uppermost horizon in the subcores.

The concentration minima in the sulfide profiles are highly unusual and difficult to explain. Minima between peaks in the sulfide profiles could indicate a sink for sulfide, by oxidation or precipitation. Oxygen and nitrate are absent below the chemocline of the Black Sea. However, atypical for Black Sea sediments, about $20-80 \mu \mathrm{mol} \mathrm{cm} \mathrm{cm}^{-3}$ amorphous and crystalline Fe(III)oxides or iron silicates and up to $150 \mu \mathrm{mol} \mathrm{L}^{-1}$ dissolved iron were detected in pore waters of the summit (data not shown) and might be responsible for the sulfide concentration minimum. Outside the summit no dissolved iron was found, concentrations of $\mathrm{Fe}(\mathrm{III})$ oxides were much lower and sulfide fluxes significantly higher. However, also here sulfide concentration minima were observed (St. 4-7). There was no dissolved iron and not enough $\mathrm{Fe}$ (III) to sustain the volumetric sulfide consumption of on average $1300 \mathrm{mmol} \mathrm{m}^{-3} \mathrm{~d}^{-1}$ for a prolonged period. With a concentration of reactive iron of maximally $20,000 \mathrm{mmol} \mathrm{m}^{-3}$ as found for the geographical center (data not shown), consumption can be maintained for about two weeks. Thus, we may have sampled a fresh mud flow not yet in steady state, or other processes must be responsible for consuming sulfide. A recent deposition and decomposition of fresh organic matter during a winter or spring bloom of Emiliania huxleyi as common in the Black Sea (Sorokin, 1983; Hay et al., 1990) could cause a non-steady state situation with two sulfide peaks. However, the sulfate reduction rates outside the mud volcano were not elevated compared to other observations in the abyssal part of the Black Sea (Jørgensen et al., 2001; Weber et al., 2001). Mud volcanoes are dynamic environments and transient state can be caused e.g. by changes in upward fluid-flow velocity, hydrate dissociation, and mud flow events. However, over short distances of several centimeter, leveling of the two concentration maxima into a straight line by diffusion is in the order of days and the observed dip must be a transient phenomenon. 


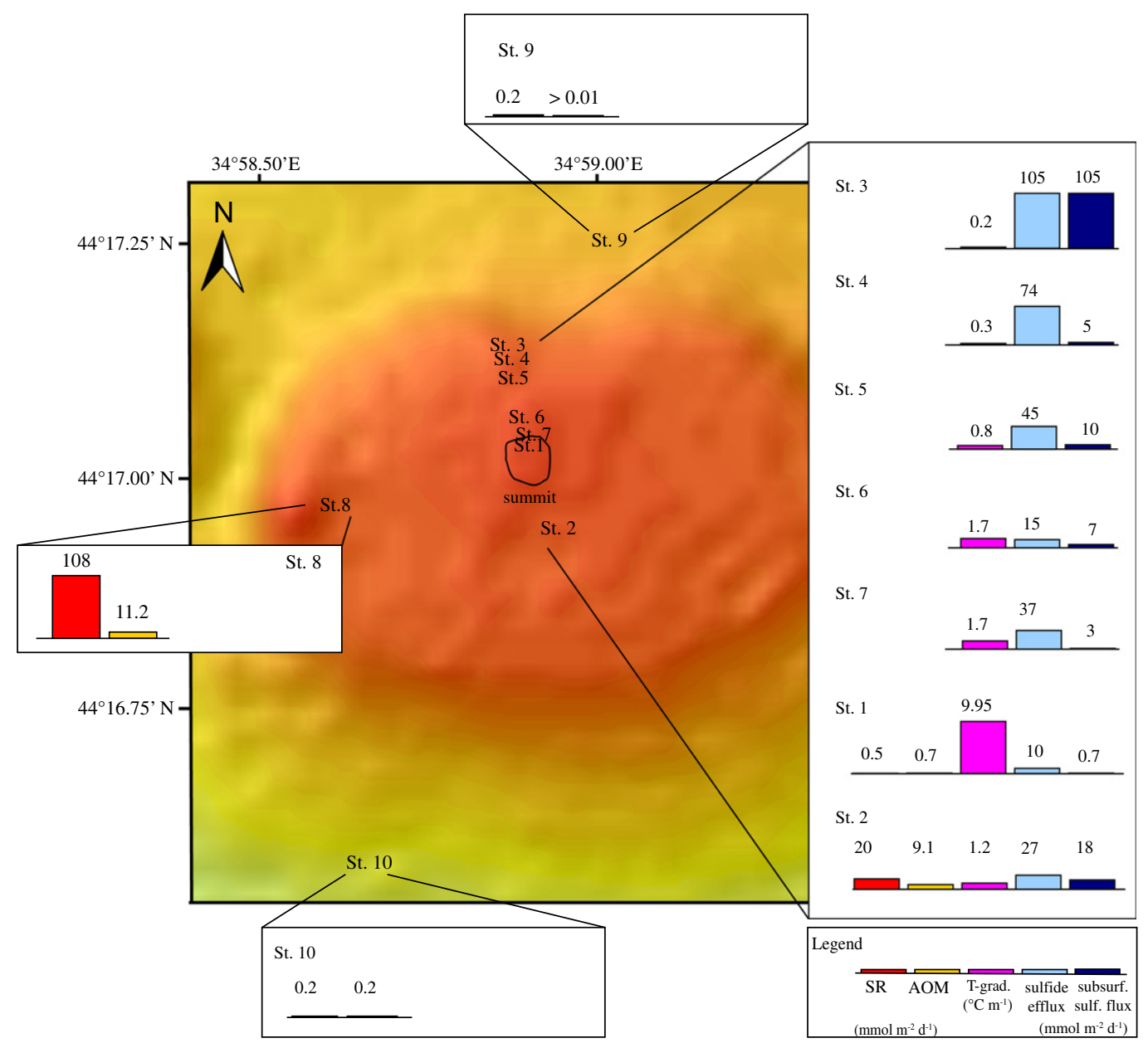

Fig. 6. Spatial distribution of SR and AOM rates, temperature gradients, sulfide effluxes to the hydrosphere (across the DBL: diffusive boundary layer), and subsurface sulfide fluxes across the DMV. The scale is the same for SR, AOM, and sulfide fluxes; the columns for temperature gradients are 10 times magnified.

As the diffusion coefficient of sulfate is around 1.7 times lower than that of sulfide (Berner, 1977; Boudreau et al., 1992), the maximal sulfide concentration at steady state conditions, under diffusional transport and complete sulfate conversion without re-oxidation, can reach $10 \mathrm{mmol} \mathrm{L}^{-1}$ in Black Sea sediments (maximal sulfate concentration is $17 \mathrm{mmol} \mathrm{L}^{-1}$ ). This value was approximated in some profiles of the DMV plateau, and the fluid upflow or the sulfide concentration might be an overestimation here. Interestingly, the sediment depths of the sulfide peaks were different in all center sites and this also implies irregularities in the fluid flow across the mud volcano surface, and disturbances by mud flow.

\subsection{Mud volcanoes as source for methane and sulfide to the Black Sea}

A main aim of this study was to investigate if submarine deep-sea mud volcanoes of the Black Sea could contribute significantly to the methane and sulfide inventory of the anoxic hydrosphere. From the shape, height, size of the conduit, and dimensions of the source of mud and methane, the DMV seems comparable to other mud volcanoes in the Sorokin Trough (Krastel et al., 2003). Furthermore, previous published estimates of fluid flow and methane discharge rate at the DMV were at an average level for mud volcanoes (Wallmann et al., 2006).

We identified an elevated zone with a radius of approximately $50 \mathrm{~m}\left(7800 \mathrm{~m}^{2}\right)$, which showed evidence of high fluid-flow velocities and methane seepage. In this small zone, temperature gradients and hence methane flux were homogeneous (Feseker et al., 2009). No methane was consumed microbially in the upper seafloor, due to a limitation in sulfate availability, and a very low cell density. Other negative effects on methane consumption are due to the anoxic conditions of the Black Sea hydrosphere, which hinder aerobic oxidation of methane as well as the stimulation of subsurface AOM by sulfate irrigation through the activity of benthic organisms. Consequently, the methane emission at the summit was very high with $1.3 \times 10^{6} \mathrm{~mol} \mathrm{yr}^{-1}$ $\left(0.46 \mathrm{~mol} \mathrm{~m}^{-2} \mathrm{~d}^{-1} \times 7800 \mathrm{~m}^{2} \times 365\right.$, Table 3). Methane emission in the surrounding plateau was not measured in situ, but can be calculated from the upflow velocity derived from the in situ sulfide profiles and the ambient 
concentration of dissolved methane. At the in situ methane concentration as estimated for methane hydrates in equilibrium with methane $\left(0.085-0.118 \mathrm{~mol} \mathrm{~L}^{-1}\right.$, Wallmann et al., 2006; Feseker et al., 2009), we determined an average methane transport of $0.07-0.1 \mathrm{~mol} \mathrm{~m}^{-2} \mathrm{~d}^{-1}$ or $1.9-2.7 \times 10^{7}$ $\mathrm{mol} \mathrm{yr}^{-1}$ for the entire DMV center area and edge $\left(7.5 \times 10^{5} \mathrm{~m}^{2}\right)$. In the plateau sediments of the DMV, methane utilization as inferred from the averaged sulfide flux $\left(0.05 \mathrm{~mol} \mathrm{~m}^{-2} \mathrm{~d}^{-1}\right.$, average of fluxes except from the summit) was $1.4 \times 10^{7} \mathrm{~mol} \mathrm{CH}_{4} \mathrm{yr}^{-1}$, i.e. between $50 \%$ and $70 \%$ of the total methane flux was consumed. Accordingly, from the entire structure (plateau including the summit) up to $1.3 \times 10^{7} \mathrm{~mol} \mathrm{CH}_{4} \mathrm{yr}^{-1}$ was discharged in form of dissolved methane, which is about an order of magnitude higher than the previous estimate of $1.9 \times 10^{6} \mathrm{~mol} \mathrm{CH}_{4} \mathrm{yr}^{-1}$ (Wallmann et al., 2006). Methane efflux has been quantified at very few mud volcanoes. Compared to other active systems like the Håkon Mosby Mud Volcano (5.4× $10^{6} \mathrm{~mol} \mathrm{CH}_{4} \mathrm{yr}^{-1}$; Ginsburg et al., 1999), mud mounds offshore Costa Rica $\left(0.07-0.6 \times 10^{6} \mathrm{~mol} \mathrm{CH}_{4} \mathrm{yr}^{-1}\right.$ per structure; Mau et al., 2006) or mud volcanoes offshore Barbados $\left(0.6-185 \times 10^{6} \mathrm{~mol} \mathrm{CH}_{4} \mathrm{yr}^{-1}\right.$ per structure; Henry et al., 1996) this is a moderate to high methane discharge. The Black Sea is the world's largest surface water reservoir of dissolved methane, with background concentrations of around $11 \mu \mathrm{mol} \mathrm{L}{ }^{-1}$, and a methane inventory of $6 \times 10^{12} \mathrm{~mol}$, with 5-20 yr turnover time (Reeburgh et al., 1991). Less than $15 \%$ of the methane comes from methanogenesis in the sediment, and seeps and gashydrates are thought to provide the remainder (Kessler et al., 2006). Even with our higher estimate for methane discharge at least 15,000 mud volcanoes with similar emission rates as the DMV would be needed to account for the Black Sea water column methane flux of $2.3-3.5 \times 10^{11} \mathrm{~mol} \mathrm{yr}^{-1}$ as estimated from Kessler et al. (2006). To date the presence of more than 65 submarine deep-sea mud volcanoes is known for the total Black Sea (Kruglyakova et al., 2002). Thus mud volcanoes are not relevant for the methane budgets of the Black Sea. Instead, gas seeps with strong and focused methane gas venting such as frequently found on shelves and slopes of the Black Sea (Polikarpov et al., 1992; Luth et al., 1999; Dimitrov, 2002; Michaelis et al., 2002) play the dominant role in the methane inventory of the Black Sea. However, it should be realized that mud volcanoes are highly dynamic systems: compared to previous studies (Greinert et al., 2006), the DMV was in a quiescent phase during our measurements with regard to gaseous methane release; however, other mud volcanoes in the Sorokin Trough were reported to be less active than the DMV (Sahling et al., 2009; Bohrmann et al., 2003).

The amount of sulfide produced in and emitted from the DMV $\left(0.05 \mathrm{~mol} \mathrm{~m}^{-2} \mathrm{~d}^{-1}\right.$, average of fluxes except from the summit) was high compared to other mud volcanoes. Generally, mud volcanoes in oxic areas of the world's oceans hardly emit any sulfide (de Beer et al., 2006; Lichtschlag et al., 2010). Free-living and symbiotic thiotrophic microbes associated with benthic fauna consume almost all sulfide produced in seafloor before it reaches the hydrosphere. This is different in the anoxic bottom waters of the deep Black Sea, where sulfide consumption is limited by the absence of oxygen and nitrate, and the depletion of highly reactive sedimentary iron- and manganese-oxides while sinking through the anoxic seawater below the pycnocline. However, compared to the total sulfide inventory of $1.4 \times 10^{14} \mathrm{~mol}$ of the Black Sea (Neretin et al., 2001), the contribution of mud volcanoes is negligible. It was previously estimated that the largest contribution to the sulfide inventory $\left(8.8 \times 10^{11}-1.5 \times 10^{12} \mathrm{~mol} \mathrm{yr}^{-1}\right)$ comes from the water column and only $9.4 \times 10^{10}-1.5 \times 10^{11} \mathrm{~mol} \mathrm{yr}^{-1}$ sulfide is derived from the sediment (Neretin et al., 2001). The $1.4 \times 10^{7} \mathrm{~mol} \mathrm{yr}^{-1}$ sulfide released from the DMV contributes maximally $0.01 \%$ to the total sediment derived sulfide content of the anoxic hydrosphere, indicating that 10,000 mud volcanoes of a similar activity as the DMV would be needed to explain a significant fraction of the sulfide inventory. Thus, although sulfate reduction and sulfide production are significant processes in the sediments of the DMV, the sulfide flux from mud volcanoes does not considerably add to the sulfide inventory of the Black Sea.

\section{CONCLUSIONS}

Our results show that the Dvurechenskii mud volcano represents an active methane seep, but also a highly dynamic ecosystem with strong spatial and temporal variations in geochemical processes. Fluid and mud flow as well as the bottom water anoxia have a significant impact on the consumption and efflux of methane and sulfide. Medium to low fluid upflow allow high sulfate and methane consumption and reduce the methane emission to the water column by circa $50-70 \%$. High fluid upflow $>1 \mathrm{~m} \mathrm{yr}^{-1}$, and the extrusion of subsurface muds depleted in microbial assemblages prevents methane oxidation and leads to very high methane emission rates of $458 \mathrm{mmol} \mathrm{m}^{-2} \mathrm{~d}^{-1}$ at the summit of the DMV. This rather small elevation north of the geographical center of the DMV shows the highest temperature gradients, but almost no microbial sulfide production is detected due to a repression of microbial activity. Our results suggest that deep-water mud volcanoes have only a small contribution on the methane and sulfide inventory of the Black Sea, and that most methane is derived from the abundant gas vents in shallower areas of the Black Sea margin.

\section{ACKNOWLEDGMENTS}

We thank the members of the shipboard crew of the RV Meteor, the Quest 4000 team (MARUM, University of Bremen), and the scientific party for the excellent support during the M72/2 Microhab cruise. Special thanks are to Gaby Eickert, Ines Schröder, Vera Hübner, Karin Hohmann, Ingrid Dohrmann and Cecilia Wiegand for providing excellent microsensors, and to Martina Alisch and Gabi Schüßler for further technical support. We thank our colleague Stefanie Grünke for preparing the sampling map. We are grateful for the support from the Sea-Tech technicians of the Microbial Habitat group (MPI) for the construction and maintenance of the in situ devices. We thank the four anonymous referees for their constructive feedback. This study was supported by the GEOTECHNOLOGIEN project MUMM II (03G0608C) funded by the German Ministry of Education and Research (BMBF) and 
German Research Foundation (DFG), by the EU FP6 program HERMES (GOCE-CT-2005-511234-1) as well as by the Max Planck Society and the MARUM - Center for Marine Environmental Sciences (funded through DFG). This is GEOTECH publication no. 1326 .

\section{REFERENCES}

Aloisi G., Drews M., Wallmann K. and Bohrmann G. (2004) Fluid expulsion from the Dvurechenskii mud volcano (Black Sea) Part I. Fluid sources and relevance to Li, B, Sr, I and dissolved inorganic nitrogen cycles. Earth Planet. Sci. Lett. 225, 347-363.

Berner R. A. (1977) Stoichiometric models for nutrient regeneration in anoxic sediments. Limnol. Oceanogr. 22, 781-786.

Blinova V. N., Ivanov M. K. and Bohrmann G. (2003) Hydrocarbon gases in deposits from mud volcanoes in the Sorokin Trough, north-eastern Black Sea. Geo-Mar. Lett. 23, 250-257.

Boetius A. and Lochte K. (1996) Effect of organic enrichments on hydrolytic potentials and growth of bacteria in deep-sea sediments. Mar. Ecol. Prog. Ser. 140, 239-250.

Boetius A., Ravenschlag K., Schubert C. J., Rickert D., Widdel F., Gieseke A., Amann R., Jørgensen B. B., Witte U. and Pfannkuche O. (2000) A marine microbial consortium apparently mediating anaerobic oxidation of methane. Nature $\mathbf{4 0 7}$, 623-626.

Bohrmann G., Ivanov M., Foucher J. P., Spiess V., Bialas J., Greinert J., Weinrebe W., Abegg F., Aloisi G., Artemov Y., Blinova V., Drews M., Heidersdorf F., Krabbenhoft A., Klaucke I., Krastel S., Leder T., Polikarpov I., Saburova M., Schmale O., Seifert R., Volkonskaya A. and Zillmer M. (2003) Mud volcanoes and gas hydrates in the Black Sea: New data from Dvurechenskii and Odessa mud volcanoes. Geo-Mar. Lett. 23, 239-249.

Boudreau B. P., Canfield D. E. and Mucci A. (1992) Early Diagenesis in a marine sapropel, Mangrove Lake, Bermuda. Limnol. Oceanogr. 37, 1738-1753.

Cline J. D. (1969) Spectrophotometric determination of hydrogen sulfide in natural waters. Limnol. Oceanogr. 14, 454-458.

Cordes E. E., Arthur M. A., Shea K., Arvidson R. S. and Fisher C. R. (2005) Modeling the mutualistic interactions between tubeworms and microbial consortia. PLoS Biol. 3, 497-506.

de Beer D., Schramm A., Santegoeds C. M. and Kühl M. (1997) A nitrite microsensor for profiling environmental biofilms. Appl. Environ. Microbiol. 63, 973-977.

de Beer D., Sauter E., Niemann H., Kaul N., Foucher J.-P., Witte U., Schlüter M. and Boetius A. (2006) In situ fluxes and zonation of microbial activity in surface sediments of the Håkon Mosby Mud Volcano. Limnol. Oceanogr. 51, 13151331.

Dickens G. R., Koelling M., Smith D. C., Schnieders L. and Party a. t. I. E. S. (2007) Rhizon sampling of pore waters on scientific drilling expeditions: An example from the IODP expedition 302 (ACEX). Scientific Drilling 4, 22-25.

Dimitrov L. (2002) Contribution to atmospheric methane by natural seepages on the Bulgarian continental shelf. Continent. Shelf Res. 22, 2429-2442.

Feseker T., Pape T., Wallmann K., Klapp S. A., SchmidtSchierhorn F. and Bohrmann G. (2009) The thermal structure of the Dvurechenskii mud volcano and its implications for gas hydrate stability and eruption dynamics. Mar. Petrol. Geol. 26, 1812-1823.

Fry B., Jannasch H. W., Molyneaux S. J., Wirsen C. O., Muramoto J. A. and King S. (1991) Stable isotope studies of the carbon, nitrogen and sulfur cycles in the Black Sea and the Cariaco Trench. Deep-Sea Res. Pt. A 38, S1003-S1019.

Ginsburg G. D., Milkov A. V., Soloviev V. A., Egorov A. V., Cherkashev G. A., Vogt P. R., Crane K., Lorenson T. D. and Khutorskoy M. D. (1999) Gas hydrate accumulation at the Håkon Mosby Mud Volcano. Geo-Mar. Lett. 19, 57-67.

Glud R. N., Stahl H., Berg P., Wenzhöfer F., Oguri K. and Kitazato H. (2009) In situ microscale variation in distribution and consumption of $\mathrm{O}_{2}$ : A case study from a deep ocean margin sediment (Sagami Bay, Japan). Limnol. Oceanogr. 54, 1-12.

Goldhaber M. B. and Kaplan I. R. (1975) Apparent dissociation constants of hydrogen sulfide in chloride solutions. Mar. Chem. 3, 83-104.

Grasshoff K., Ehrhardt M. and Kremling K. (1983) Methods of Seawater Analysis. Verlag Chemie, Weinheim.

Greinert J., Artemov Y., Egorov V., De Batist M. and McGinnis D. (2006) 1300-m-high rising bubbles from mud volcanoes at $2080 \mathrm{~m}$ in the Black Sea: Hydroacoustic characteristics and temporal variability. Earth Planet. Sci. Lett. 244, 1-15.

Gundersen J. K. and Jørgensen B. B. (1990) Microstructure of diffusive boundary layers and the oxygen uptake of the sea floor. Nature 345, 604-607.

Haese R. R., Meile C., Van Cappellen P. and de Lange G. J. (2003) Carbon geochemistry of cold seeps: Methane fluxes and transformation in sediments from Kazan mud volcano, eastern Mediterranean Sea. Earth Planet. Sci. Lett. 212, 361-375.

Haese R. R., Hensen C. and de Lange G. J. (2006) Pore water geochemistry of eastern Mediterranean mud volcanoes: Implications for fluid transport and fluid origin. Mar. Geol. 225, 191208.

Hall P. O. and Aller R. C. (1992) Rapid, small-volume, flow injection analysis for $\Sigma \mathrm{CO}_{2}$ and $\mathrm{NH}_{4}{ }^{+}$in marine and freshwaters. Limnol. Oceanogr. 37, 1113-1119.

Hay B. J., Honjo S., Kempe S., Ittekkot V. A., Degens E. T., Konuk T. and Izdar E. (1990) Interannual variability in particle flux in the southwestern Black Sea. Deep-Sea Res. Pt. A 37, 911-928.

Henry P., LePichon X., Lallemant S., Lance S., Martin J. B., Foucher J.-P., Fiala-Medioni A., Rostek F., Guilhaumou N., Pranal V. and Castrec M. (1996) Fluid flow in and around a mud volcano field seaward of the Barbados accretionary wedge: Results from Manon cruise. J. Geophys. Res.-Sol. Ea. 101, 20297-20323.

Hensen C., Wallmann K., Schmidt M., Ranero C. R. and Suess E. (2004) Fluid expulsion related to mud extrusion off Costa Rica - A window to the subducting slab. Geology 32, 201-204.

Hinrichs K. U., Hayes J. M., Sylva S. P., Brewer P. G. and DeLong E. F. (1999) Methane-consuming archaebacteria in marine sediments. Nature 398, 802-805.

Ivanov M. V. and Lein A. Y. (2006) Fractionation of stable isotopes of carbon and sulfur during biological processes in the Black Sea. In Past and Present Water Column Anoxia (ed. L. Neretin). Springer, Netherlands.

Iversen N. and Jørgensen B. B. (1993) Diffusion coefficients of sulfate and methane in marine sediments: Influence of porosity. Geochim. Cosmochim. Acta 57, 571-578.

Jeroschewski P., Steuckart C. and Kühl M. (1996) An amperometric microsensor for the determination of $\mathrm{H}_{2} \mathrm{~S}$ in aquatic environments. Anal. Chem. 68, 4351-4357.

Jørgensen B. B. (1978) A comparison of methods for the quantification of bacterial sulfate reduction in coastal marine sediments: 1. Measurements with radiotracer techniques. Geomicrobiol. J. 1, 11-27.

Jørgensen B. B., Weber A. and Zopfi J. (2001) Sulfate reduction and anaerobic methane oxidation in Black Sea sediments. DeepSea Res. Pt. I 48, 2097-2120. 
Kallmeyer J., Ferdelman T. G., Weber A., Fossing H. and Jørgensen B. B. (2004) A cold chromium distillation procedure for radiolabeled sulfide applied to sulfate reduction measurements. Limnol. Oceanogr.: Methods 2, 171-180.

Kessler J. D., Reeburgh W. S., Southon J., Seifert R., Michaelis W. and Tyler S. C. (2006) Basin-wide estimates of the input of methane from seeps and clathrates to the Black Sea. Earth Planet. Sci. Lett. 243, 366-375.

Knittel K., Boetius A., Lemke A., Eilers H., Lochte K., Pfannkuche O., Linke P. and Amann R. (2003) Activity, distribution, and diversity of sulfate reducers and other bacteria in sediments above gas hydrate (Cascadia margin, Oregon). Geomicrobiol. J. 20, 269-294.

Krastel S., Spiess V., Ivanov M., Weinrebe W., Bohrmann G., Shashkin P. and Heidersdorf F. (2003) Acoustic investigations of mud volcanoes in the Sorokin Trough, Black Sea. Geo-Mar. Lett. 23, 230-238.

Kruglyakova R., Gubanov Y., Kruglyakov V. and Prokoptsev G. (2002) Assessment of technogenic and natural hydrocarbon supply into the Black Sea and seabed sediments. Continent. Shelf Res. 22, 2395-2407.

Kvenvolden K. A., McDonald T. J. (1986) Organic geochemistry on the JOIDES Resolution - an essay. ODP Tech. Note 6.

Li Y.-H. and Gregory S. (1974) Diffusion of ions in sea water and in deep-sea sediments. Geochim. Cosmochim. Acta 38, 703-714.

Lichtschlag A., Felden J., Brüchert V., Boetius A. and de Beer D. (2010) Geochemical processes and chemosynthetic primary production in different thiotrophic mats of the Håkon Mosby Mud Volcano (Barents Sea). Limnol. Oceanogr. 55, 931-949.

Linke P., Wallmann K., Suess E., Hensen C. and Rehder G. (2005) In situ benthic fluxes from an intermittently active mud volcano at the Costa Rica convergent margin. Earth Planet. Sci. Lett. 235, 79-95.

Lösekann T., Knittel K., Nadalig T., Fuchs B., Niemann H., Boetius A. and Amann R. (2007) Diversity and abundance of aerobic and anaerobic methane oxidizers at the Haakon Mosby Mud Volcano, Barents Sea. Appl. Environ. Microbiol. 73, 33483362.

Luth C., Luth U., Gebruk A. V. and Thiel H. (1999) Methane gas seeps along the oxic/anoxic gradient in the Black Sea: Manifestations, biogenic sediment compounds and preliminary results on benthic ecology. Mar. Ecol. 20, 221-249.

Mau S., Sahling H., Rehder G., Suess E., Linke P. and Soeding E. (2006) Estimates of methane output from mud extrusions at the erosive convergent margin off Costa Rica. Mar. Geol. 225, 129144.

Meyer-Reil L.-A. (1983) Benthic response to sedimentation events during autumn to spring at a shallow water station in the Western Kiel Bight: 2. Analysis of benthic bacterial populations. Mar. Biol. 77, 247-256.

Michaelis W., Seifert R., Nauhaus K., Treude T., Thiel V., Blumenberg M., Knittel K., Gieseke A., Peterknecht K., Pape T., Boetius A., Amann R., Jørgensen B. B., Widdel F., Peckmann J. R., Pimenov N. V. and Gulin M. B. (2002) Microbial reefs in the Black Sea fueled by anaerobic oxidation of methane. Science 297, 1013-1015.

Neretin L. N., Volkov I. I., Böttcher M. E. and Grinenko V. A. (2001) A sulfur budget for the Black Sea anoxic zone. Deep-Sea Res. Pt. I 48, 2569-2593.

Niemann H., Lösekann T., de Beer D., Elvert M., Nadalig T., Knittel K., Amann R., Sauter E. J., Schlüter M., Klages M., Foucher J.-P. and Boetius A. (2006) Novel microbial communities of the Haakon Mosby mud volcano and their role as a methane sink. Nature 443, 854-858.

Orcutt B. N., Boetius A., Lugo S. K., MacDonald I. R., Samarkin V. A. and Joye S. B. (2004) Life at the edge of methane ice:
Microbial cycling of carbon and sulfur in Gulf of Mexico gas hydrates. Chem. Geol. 205, 239-251.

Omoregie E. O., Mastalerz V., de Lange G., Straub K. L., Kappler A., Røy H., Stadnitskaia A., Foucher J. P. and Boetius A. (2008) Biogeochemistry and community composition of ironand sulfur-precipitating microbial mats at the Chefren mud volcano (Nile Deep Sea Fan, Eastern Mediterranean). Appl. Environ. Microbiol. 74, 3198-3215.

ODP Leg 201 Shipboard Scientific Party. Explanatory Notes (2003) In Proc. ODP, Init. Repts (eds. S. L. D'Hondt, B. B. Jørgensen, D. J. Miller et al.), 201 [Online]. http://www-odp. tamu.edu/publication/201_IR/chap_05/chap_05.htm.

Polikarpov G. G., Egorov V. N., Gulin S. B., Gulin M. B. and Stokozov N. A. (1992) Gas seeps from the bottom of the Black Sea - a new object of molismology. In Molismology of the Black Sea (ed. G. G. Polikarpov). Nauka, Kiev.

Reeburgh W. S., Ward B. B., Whalen S. C., Sandbeck K. A., Kilpatrick K. A. and Kerkhof L. J. (1991) Black Sea methane geochemistry. Deep-Sea Res. Pt. A 38, S1189-S1210.

Sahling H., Bohrmann G., Artemov Y. G., Bahr A., Bruning M., Klapp S. A., Klaucke I., Kozlova E., Nikolovska A., Pape T., Reitz A. and Wallmann K. (2009) Vodyanitskii mud volcano, Sorokin trough, Black Sea: Geological characterization and quantification of gas bubble streams. Mar. Petrol. Geol. 26, 1799-1811.

Schmidt K., Koschinsky A., Garbe-Schönberg D., de Carvalho L. M. and Seifert R. (2007) Geochemistry of hydrothermal fluids from the ultramafic-hosted Logatchev hydrothermal field, 15 degrees $\mathrm{N}$ on the Mid-Atlantic Ridge: Temporal and spatial investigation. Chem. Geol. 242, 1-21.

Seeberg-Elverfeldt J., Schlüter M., Feseker T. and Kolling M. (2005) Rhizon sampling of porewaters near the sediment-water interface of aquatic systems. Limnol. Oceanogr.: Methods 3, 361-371.

Sommer S., Linke P., Pfannkuche O., Schleicher T., von Deimling J. S., Reitz A., Haeckel M., Flogel S. and Hensen C. (2009) Seabed methane emissions and the habitat of frenulate tubeworms on the Captain Arutyunov mud volcano (Gulf of Cadiz). Mar. Ecol. Prog. Ser. 382, 69-86.

Sorokin Y. I. (1983) The Black Sea. In Ecosystems of the World. Estuaries and Enclosed Seas (ed. B. H. Ketchum). Elsevier, Amsterdam.

Torres M. E., McManus J., Hammond D. E., de Angelis M. A., Heeschen K. U., Colbert S. L., Tryon M. D., Brown K. M. and Suess E. (2002) Fluid and chemical fluxes in and out of sediments hosting methane hydrate deposits on Hydrate Ridge, OR, I: Hydrological provinces. Earth Planet. Sci. Lett. 201 , 525-540.

Treude T., Boetius A., Knittel K., Wallmann K. and Jørgensen B. B. (2003) Anaerobic oxidation of methane above gas hydrates at Hydrate Ridge, NE Pacific Ocean. Mar. Ecol. Prog. Ser. 264, $1-14$.

Treude T., Smith C. R., Wenzhöfer F., Carney E., Bernardino A. F., Hannides A. K., Krüger M. and Boetius A. (2009) Biogeochemistry of a deep-sea whale fall: Sulfate reduction, sulfide efflux and methanogenesis. Mar. Ecol. Prog. Ser. 382, 1-21.

Wallmann K., Drews M., Aloisi G. and Bohrmann G. (2006) Methane discharge into the Black Sea and the global ocean via fluid flow through submarine mud volcanoes. Earth Planet. Sci. Lett. 248, 545-560.

Weber A., Riess W., Wenzhöfer F. and Jørgensen B. B. (2001) Sulfate reduction in Black Sea sediments: In situ and laboratory radiotracer measurements from the shelf to $2000 \mathrm{~m}$ depth. DeepSea Res. Pt. I 48, 2073-2096.

Wenzhöfer F., Holby O., Glud R. N., Nielsen H. K. and Gundersen J. K. (2000) In situ microsensor studies of a shallow 
water hydrothermal vent at Milos, Greece. Mar. Chem. 69, $43-54$.

Woodside J., Ivanov M. K., and Limonov A. F. (1997) Neotectonics and Fluid Flow Through Seafloor Sediments in the Eastern Mediterranean and Black Sea, Preliminary Results of the Geological and Geophysical Investigations during the
ANAXIPROBE/TTR-6 Cruise of the R/V Gelendzhik (JulyAugust 1996). UNESCO, Paris.

Associate editor: Jack J. Middelburg 